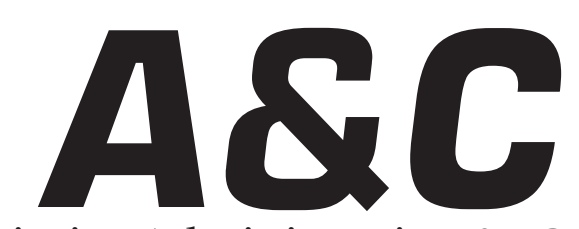

Revista de Direito Administrativo \& Constitucional

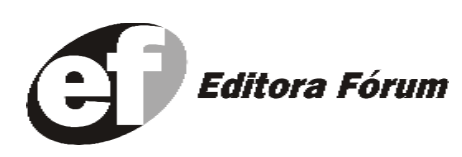

A\&C R. de Dir. Administrativo e Constitucional, Belo Horizonte, ano 4, n.18, p. 1-255, out./dez. 2004 


\section{A\&C REVISTA DE DIREITO ADMINISTRATIVO E CONSTITUCIONAL}

\section{IPDA}

Instituto Paranaense

de Direito Administrativo

Direção Geral

Romeu Felipe Bacellar Filho

Direção Editorial

Paulo Roberto Ferreira Motta

Direção Executiva

Emerson Gabardo

Conselho de Redação

Edgar Chiuratto Guimarães

Adriana da Costa Ricardo Schier

Célio Heitor Guimarães

Conselho Editorial

Adilson Abreu Dallari Luís Enrique Chase Plate

Alice Gonzáles Borges Lúcia Valle Figueiredo

Carlos Ari Sundfeld Manoel de Oliveira Franco Sobrinho (in memoriam)

Carlos Ayres Britto Marçal Justen Filho

Carlos Delpiazzo Marcelo Figueiredo

Cármen Lúcia Antunes Rocha Márcio Cammarosano

Celso Antônio Bandeira de Mello Maria Cristina Cesar de Oliveira

Clèmerson Merlin Clève Nelson Figueiredo

Clóvis Beznos Odilon Borges Junior

Enrique Silva Cimma Pascual Caiella

Eros Roberto Grau Paulo Eduardo Garrido Modesto

Fabrício Motta Paulo Henrique Blasi

Guilhermo Andrés Muñoz (in memoriam) Paulo Neves de Carvalho (in memoriam)

Jaime Rodríguez-Arana Muñoz Paulo Ricardo Schier

Jorge Luís Salomoni Pedro Paulo de Almeida Dutra

José Carlos Abraão Regina Maria Macedo Nery Ferrari

José Eduardo Martins Cardoso Rogério Gesta Leal

José Luís Said Rolando Pantoja Bauzá

José Mario Serrate Paz Sérgio Ferraz

Juan Pablo Cajarville Peruffo Valmir Pontes Filho

Juarez Freitas Yara Stropa

Julio Rodolfo Comadira Weida Zancaner

Os conceitos emitidos em trabalhos assinados são de responsabilidade de seus autores, que gozam de inteira liberdade de opinião.e-mail para remessa de artigos, pareceres e contribuições: e.gab.@uol.com.br

ou conselho@editoraforum.com.br Endereço para envio de contribuições: Editora Fórum

Revista A\&C, Av. Afonso Pena, 2770, 15\%16ª andar, Funcionários, CEP 30130-007 - Belo Horizonte - MG

A\&C Revista de Direito Administrativo e Constitucional. Ano 3, n. 11, jan./mar. 2003. Belo Horizonte: Fórum, 2003.

Trimestral

ano 1, n.1, 1999 até ano 2, n.10, 2002 publicada pela Editora Juruá em Curitiba

ISSN: $1516-3210$

1. Direito Administrativo. 2. Direito Constitucional. I. Fórum.

CDD: 342 CDU: 33.342
Editor responsável: Luis Cláudio Rodrigues Ferreira Projeto gráfico: Luis Alberto Pimenta

Diagramação: Luis Alberto Pimenta

Revisora: Olga M. A Sousa

Pesquisa jurídica: Fátima Ribeiro - OAB/MG 74868 Bibliotecária: Nilcéia Lage de Medeiros -

CRB 1545/MG - $6^{\mathrm{a}}$ região

(C) Editora Fórum Ltda 2004.

Proibida a reprodução total ou parcial desta obra,

por qualquer meio eletrônico, inclusive por processos xerográficos, sem autorização expressa do editor.

Distribuída em todo o território nacional

Assinaturas e comercialização:

Editora Fórum, Av. Afonso Pena, 2770, 15-16 andar, Funcionários, CEP 30130-007 - Belo Horizonte - MG Tel.: (31) 2121-4900 - 0800 704-3737

e-mail: editoraforum@editoraforum.com.br site: www.editoraforum.com.br 


\title{
Os Princípios Constitucionais da Administração Pública a Partir da Filosofia Hermenêutica: Condições de Possibilidade para Ultrapassar o Pensar Objetificante
}

\author{
Leonel Ohlweiler
}

Procurador de Justiça. Mestre e Doutor em Direito. Professor da Graduação e do PPGD da UNISINOS

\begin{abstract}
Sumário: Introdução - 1 A construção do estatuto científico do Direito Administrativo. A tradição exegético-racionalista como pré-compreensão - 1.1 O modo-de-ser da modernidade como determinante dos princípios epocais do Direito Administrativo: formalismo, hierarquização, centralização e segurança jurídica - 1.2 A razão legal da Revolução Francesa como fundamento metafísico das práticas administrativas - 1.3 Do caráter de acessoriedade (hermenêutica) dos princípios (da Administração Pública) para a racionalidade metodológica - 2 O novo significado para o "compreender" dos princípios constitucionais da Administração Pública a partir da hermenêutica filosófica e da filosofia hermenêutica - 2.1 A compreensão possui um caráter histórico - 2.2 A compreensão não depende de métodos e o problema da técnica - 2.3 A importância da linguagem na compreensão - 3 A Applicatio dos Princípios Constitucionais da Administração Pública - 3.1 O caráter prático de toda interpretação dos princípios constitucionais da Administração Pública: ultrapassando a dicotomia questão de fato/questão de direito - 3.2 O caráter circular (não linear) da interrogação dos princípios constitucionais da Administração Pública - 3.3 A (necessária) compreensão ponderada do interesse público: ultrapassando as dicotomias metafísicas da modernidade - Considerações finais - Referências
\end{abstract}

\section{Introdução}

O tema da presente investigação relaciona-se com a incessante tarefa de construir um Direito Administrativo fundado em bases hermenêuticas e vocacionado para criar as condições de possibilidade para o acontecer do Estado Democrático de Direito. Urge, assim, indicar as chamadas crises paradigmáticas das construções teóricas sobre os princípios constitucionais da Administração Pública, construídas a partir de um modo-de-ser ainda primordialmente liberal-individualista e alimentadas pela filosofia da consciência. ${ }^{1}$ A filosofia hermenêutica, bem como, a hermenêutica filosófica, constituem-se em matrizes teóricas privilegiadas para possibilitar o que se poderia denominar de ontologização ${ }^{2}$ do regime administrativo,

\footnotetext{
Constitui-se na crise de dupla face do Direito da qual fala Lenio Luiz Streck (Hermenêutica Jurídica e $(m)$ Crise. 4. ed. Porto Alegre: Liv. do Advogado, 2003).
} 
quer dizer, um olhar pré-ocupado pelo sentido dos entes jurídicoadministrativos, assumindo importância o horizonte do constitucionalismo moderno.

Na primeiro parte deste breve estudo serão indicadas as bases racionalistas que alimentaram a construção do Direito Administrativo, bem como a influência do fundamento construído a partir da Revolução Francesa, passando-se, ainda, pela problematização da teoria dos princípios da Administração Pública. Após, no intuito de estabelecer um diálogo com a tradição, assume capital importância as concepções filosóficas de Hans-Georg Gadamer e Martin Heidegger, capazes de abrirem novas possibilidades da própria compreensão. Na terceira parte, fundado nas matrizes teóricas já indicadas, os princípios constitucionais da Administração Pública serão tematizados, em especial a partir da applicatio e da circularidade hermenêutica. Por fim, a título exemplificativo, o princípio do interesse público, tradicionalmente construído como supremacia será abordado com a finalidade de indicar alguns caminhos para ultrapassar o pensar objetificador.

Certamente, trata-se do início de um conjunto de investigações a serem realizadas no âmbito do Direito Administrativo, não se pretendendo esgotar a temática, mas antes abrir novas sendas, capazes de aprofundar o debate sobre o tema dos princípios constitucionais da Administração Pública.

\section{A construção do estatuto científico do Direito Administrativo.}

A tradição exegético-racionalista como pré-compreensão

\subsection{0 modo-de-ser da modernidade como determinante dos} princípios epocais do Direito Administrativo: formalismo, hierarquização, centralização e segurança jurídica

O Estado Moderno, surgido a partir do final do século XV, início do século XVI, foi corolário do próprio imaginário racionalista do período. Descabe aqui estabelecer a discussão sobre a ocorrência efetiva de descontinuidade ou não entre esta forma de organização político-social e aquela do período medieval. ${ }^{3}$ No entanto, não se pode desconhecer que as

\footnotetext{
2 Muito embora não se desconheça diferenciados modos de compreender esta expressão, "ontologia", neste estudo adota-se a concepção de Martin Heidegger, significando a problematização do ser (sentido) pelo homem. Com relação a este aspecto, assim referiu Lenio Luiz Streck: "Heidegger situa a questão da ontologia fundamental no sentido do ser; a clarificação desta questão somente pode resultar do recurso ao único ente que compreender ser, que é o homem (Dasein), o estar-aí, que é o ser-no-mundo, que é cuidado (Sorge); cuidado é temporal (zeitlich)", (Hermenêutica Jurídica e $(m)$ Crise. Uma exploração hermenêutica da construção do Direito, p. 190.

3 Sobre a questão ver STRECK, Lenio Luiz e MORAIS, José Luis Bolzan. Ciência Política e Teoria Geral do Estado, p. 24-25.
} 
transformações ocorridas são fruto da insatisfação com o mundo medieval, assumindo crucial importância o surgimento de uma nova mentalidade, qual seja, o humanismo, considerando a incapacidade da Igreja em fornecer elementos de organização para um mundo tomado por problemas de ordem social e econômica. ${ }^{4}$ Surge, assim, como grande modus operandi para garantir as demandas capitalistas da época a razão. Como refere Manuel Calvo García, "la razón va a ser el hilo conductor de la progresiva secularización del pensamiento práctico moderno y la seguridad es la luz que guía y alumbra ese proceso". ${ }^{5}$

Com efeito, na gênese do Estado Moderno está a necessidade de racionalizar o exercício do poder, aliada à crescente exigência de segurança, possibilitando um agir calculado e previsível. Além da concentração de poder, fulcrada no critério territorial, buscava-se a criação de um aparato administrativo, dotando o Poder Público de diversas prerrogativas para alcançar finalidades específicas. Dando continuidade ao processo de despatrimonialização do poder, determinante para o enfraquecimento do feudalismo, no Estado Moderno ocorreu a despersonalização deste poder, passando a sua titularidade para o Estado. É claro, é preciso compreender, a ânsia de um pensamento racional, em última análise, tinha por objetivo a substituição de uma forma de pensar medieval. Na base do pensamento renascentista encontra-se a tentativa de resgatar a dimensão do homem a partir da natureza, o que, comparado com as anteriores formulações teocêntricas, representou um progresso sensível. A razão era substituída pela fé. No entendimento de Juan Ramón Capella "durante algum tempo o cometa da razão calculista que promete um mundo feliz recorrerá ao firmamento das idéias: um mundo crescentemente próspero e iluminado, um mundo de progresso (...) um mundo que se supõe organizado racionalmente" ${ }^{6}$ Como corolário, formar-se-á um conjunto de conceitos secularizados como soberania, cidadania, revolução, etc. A concepção de ciência, como já mencionado, valoriza a abstração, não desenvolvendo a forma de pensar calcada em coisas particulares. O conhecimento poderia adquirir este "status" somente quando teorizasse com categorias gerais, o

4 Cf GARCÍA, Manuel Calvo. Los Fundamentos del Método Jurídico: una Revisión Crítica, p. 32.

5 Los Fundamentos del Método Jurídico: una Revisión Crítica, p. 32.

6 CAPELLA, Juan Ramón. Fruta Prohibida, p. 103. Portanto, esta concepção de homem e de mundo, por óbvio, influenciará a estruturação do Direito Administrativo, a organização do Estado e o exercício dos poderes públicos. Haverá uma crescente tendência cientificista de racionalização do regime da Administração Pública, buscando, assim, sistematizar em detalhes os institutos jurídicos. Este ideal, no entanto, até hoje parece dominar as práticas dogmatistas do Direito.

A \& C R. de Dir. Administrativo e Constitucional, Belo Horizonte, ano 4, n. 18, p. 107-145, out./dez. 2004 
que, em última análise, importava em adotar um determinado ponto de vista para estabelecer explicações, bem como criar uma seletividade da realidade. ${ }^{7}$ No entanto, um dos graves problemas gerados pela vivência moderna para a construção das ciências, foi aquilo que Hans-Georg Gadamer denominou ao longo de toda sua obra: a recusa dos prejuízos. Para este filósofo "desde luego es cierto que tanto el movimento de la Ilustración en la Edad Moderna como sua conciencia científica reposan sobre el rechazo de los prejuicios, y que isto implica no aceptar tampoco la mera apelación a la autoridad". ${ }^{8}$ Assim, a Ciência Jurídica construída a partir do edifício de experiências da modernidade, no intuito de dotar-se de objetividade, deixou de questionar os próprios juízos prévios determinantes de toda a compreensão dos entes jurídicos.

Dentro desta tendência para a racionalização, deve ser feito o exame do Direito Administrativo, adquirindo grande importância, não apenas como marco histórico, mas, sobretudo pelo desvelar de uma nova linguagem, a Revolução Francesa.

\subsection{A razão legal da Revolução Francesa como fundamento metafísico das práticas administrativas}

O século XVIII institucionalizou uma nova mentalidade utópica como forma de ultrapassar a decadência moral, política e social da Idade Média, ${ }^{9}$ acreditando ser possível descobrir por meio da razão os princípios básicos de uma legislação perfeita, bem como supor que o intérprete pode chegar a concretizar hermeneuticamente esta legislação, por meio de procedimentos lógico-formais. A compreensão de princípios jurídicos encontrava-se permeada pela idéia de construção de princípios universais e imutáveis, inerentes à própria natureza humana, que serviriam como instrumento de limitação do poder régio, constituindo-se, em última análise, emanações

\footnotetext{
Cf. CAPELLA, Juan Ramón. Fruta Prohibida, p. 104. O autor refere que um dos aspectos criticáveis da razão moderna reside exatamente nesta sua tendência para o abstrato, o que não implica em construir uma análise pobre, pelo contrário. O produto desta forma de pensar durante o período renascentista foi muito rico. Faz-se mister salientar, no entanto, a inadequação deste modo de pensar, em especial, para o mundo atual, cheio de complexidades, na medida em que a generalidade ocasiona uma miopia para as especificidades. O específico, o particular, não pode possuir a pecha de irrelevante e que não deve ser considerado em uma análise científica. Na Ciência Jurídica, em especial no Direito Administrativo pósrevolução francesa, conforme será examinado posteriormente, está presente esta marca.

8 GADAMER, Hans-Georg. Hermenéutica y Autoridad, p. 60.

9 Cf. GARCIA, Manuel Calvo. Los Fundamentos del Método Jurídico, p. 65. Esta afirmação do autor não pode desconhecer a importância exercido pelo pensamento filosófico medieval e o contributo para a construção do imaginário moderno. Sobre o tema ver GILSON, Etienne. A Filosofia na Idade Média. São Paulo: Martins Fontes, 2001 e SCHUBACK, Márcia Sá Cavalcanti. Para ler os medievais. Ensaio de hermenêutica imaginativa. Rio de Janeiro: Vozes, 2000.
} 
de um tipo abstrato de homem. ${ }^{10} \mathrm{~A}$ esta forma de compreender o Direito, alia-se a concepção democrática fundada na soberania nacional e que será responsável, conforme será examinado, pela manutenção da autoridade da lei, ou seja, como fruto dos representantes do povo, é considerada como fonte exclusiva do Direito, constituindo-se em elemento capaz de racionalizar a própria sociedade.

A lei, portanto, é vislumbrada por intermédio de uma idéia abstrata, cujo sentido objetivo seria capaz, no âmbito do regime administrativo, de fornecer as soluções dos casos concretos surgidos em razão da atuação do Estado. Ademais, a solução adotada seria exatamente aquela previamente fixada pela legislação. No entendimento de Manuel Calvo García, "dos son los factores determinantes de la nueva ideologia lógico-dedutiva que va a caracterizar desde este momento el método jurídico: la matematización de los juegos de verdad y la profundidad que cobra la ideia de sistema". ${ }^{11}$ A incorporação da forma matemática de raciocinar e construir o conhecimento acabou influenciando o Direito, impondo como objetivo científico a necessidade de construir um sistema perfeito e capaz de atender os ideais de segurança e certeza. Os princípios jurídicos, com efeito, seriam mentados pela dogmática jurídico-administrativa como elementos axiomáticos e conceituais de uma racionalidade formal, buscando-se romper com o anterior paradigma autoritário do "ancien régime". Tais princípios poderiam, a partir da metodologia apropriada, serem extraídos de um conjunto legislativo perfeito, de modo a fornecer imediatamente a solução para o caso concreto.

Aqui pode-se encontrar as raízes do método dedutivo, pois a necessidade de buscar uma decisão coerente com o sistema jurídico faz pressupor que toda decisão jurídica pode consistir na aplicação de um preceito geral e abstrato a um fato concreto. ${ }^{12}$ A metodologia racionalista, e que tanto influenciou a formacião do conjunto de princípios do regime administrativo, Evolução. Lisboa: Universidade Católica Editora, 1994, p. 264: "Constituído por princípios universais sobre as relações humanas, enquanto emanações de um tipo abstracto de Homem, o direito natural racionalista, aliado à soberania nacional, é, em grande medida responsável pela uniformidade da onda política revolucionária que, sobrepondo-se às fronteiras dos diferentes Estados, une os povos num desejo comum de liberdade e igualdade - a concepção liberal repousando sobre a defesa da liberdade, junta-se à concepção democrática apoiada na soberania nacional".

${ }^{11}$ GARCIA, Manuel Calvo. Los Fundamentos del Método Jurídico, p. 40 . O autor menciona que as tentativas de aprofundamento epistemológico nesta época estavam impregnadas pela fé absoluta na ordem matemática do conhecer. A verdade, portanto, seria um valor puramente lógico, constituindo-se na mesma coisa que proposição verdadeira. Vale aqui, por exemplo, referir o pensamento de Thomas Hobbes, para quem a razão seria, por si mesma, a razão exata, como a aritimética é uma arte certa e infalível.

${ }^{12} \mathrm{Na}$ base desta forma de pensamento é possível identificar algumas formulações teóricas típicas do Estado Moderno. Por exemplo, para Thomas Hobbes, o autor que rompe definitivamente com o método aristotélico, a lei seria um mandato que expressa a vontade do soberano e recebe a sua autoridade exclusivamente do 
permite tornar plausíveis metodologicamente os postulados da plenitude, harmonia, universalidade e intemporalidade da lei positiva, determinando a simbiose moderna entre poder e razão. Tais formulações, como lembra Manoel Calvo Garcia, são propícias para acolher os ideais da classe burguesa

El método lógico-deductivo se acomoda perfectamente a los ideales burgueses de seguridad juridica. En los orígenes del mundo moderno, la lucha por la seguridad se vincula con la necesidad de poner orden en un mundo social y moralmente desgarrado. Sin orden no hay seguridad y, como consecuencia, no existe la posibilidad de calcular racionalmente los resultados de la actividad económica... ${ }^{13}$

Com efeito, no bojo desta sistemática estava a concepção de racionalidade formal, o que acaba sendo determinante para as construções teóricas sobre o conjunto de prerrogativas e limitações do Estado. A exigência de tal espécie de racionalidade, por outro lado, estava ligada diretamente ao princípio da igualdade formal que consagra o novo Estado de direito burguês, e a generalidade que possibilita superar as contingências inerentes ao casuísmo, viabilizando a exata aplicação da lei. Tal forma de concretizar o Direito estabelecia a aparência de isenção na regulação das situações típicas, bem como contribui para dotar o direito burguês de seu caráter ideológico, ou seja, o converte em um sistema capaz de desmascarar a realidade social, apresentando-a como o reino juridicizado e carente de conflitos ou compromissos materiais, a instância neutra que garantiria o livre jogo das leis naturais da vida social. ${ }^{14}$

A Revolução Francesa, desta forma, contribuiu para que fosse formulada uma concepção do império da soberania da lei como ideal político, como aduz Eduardo Garcia de Enterría, ${ }^{15}$ "en el fondo, esta formulación del império o de la soberania de la Ley como ideal político no es más que una transposición a la teoria social del principio de legalidad del universo sobre el que trabaja el pensamiento de Occidente desde el Renacimento

fato de representar a própria vontade do soberano. Estabelece-se a personificação da idéia do legislador racional, o que possibilita defender a noção de coerência sistemática da lei. Portanto, o Estado seria a expressão absoluta da razão, não podendo surgir facilmente uma contradição nas leis e, mesmo quando tal ocorresse, a mesma razão seria capaz, por meio de interpretação, de eliminar tal incoerência, cf. GARCIA, Manuel Calvo. Los Fundamentos del Método Jurídico, p. 45.

13 GARCIA, Manuel Calvo. Los Fundamentos del Método Jurídico, p. 60.

${ }^{14} \mathrm{Cf}$. GARCIA, Manuel Calvo. Los Fundamentos del Método Jurídico, p. 70. Dentro da concepção racionalista são fundamentais os seguintes princípios orientadores: a) o mundo constitui-se em um sistema ordenado, regido por leis universais e necessárias; b) o homem é um ser racional, dotado, de capacidade para compreender tal legislação objetiva e c) a ciência consiste no descobrimento e formalização de ditas leis, através de proposições universais dotadas de idêntica necessariedade e universalidade que seu objeto, cf. PUCEIRO, Enrique Zuleta. Paradigma Dogmatico y Ciencia del Derecho, p. 24.

${ }^{15}$ Revolucion Francesa y Administracion Contemporânea. 4. ed. Madrid: Civitas, 1998, p. 22. 
y que alcanza en la Física de Newton y en la Ilustración su expresión definitiva". A lei constituiu-se em instrumento de representação da razão, da racionalidade, pois por intermédio dela estar-se-ia garantindo estabilidade, em oposição ao particularismo, bem como salvaguardando o "interesse geral", devido ao seu caráter impessoal, capaz de criar uma unidade. Neste aspecto, foi significativo o contributo de Rosseau ao construir o dogma da vontade geral, caracterização nitidamente metafísica.

Para os fins da presente pesquisa, metafísica significa uma forma de pensar calcada na concepção de fundamento último, ou seja, um determinado ponto de partida extremo que não comporta nada que esteja além dele. Outrossim, os entes "com seus traços mais gerais, por seu lado, são as vigas e as colunas, que, partindo do alicerce, da causa primeira, montam e sustentam a estrutura da construção". ${ }^{16}$ A lei, encarnando a chamada vontade geral do povo, assume a configuração de um ponto de partida absoluto das práticas administrativas, além de atribuir-lhe uma necessária abstração, como modo de salvaguardar o necessário distanciamento do administrador. A compreensão auto-referencial afigura-se como outra característica da metafísica, ou seja, somente mostra-se como um conhecimento válido, legítimo, aquele produzido desde os seus próprios enunciados, a partir dos quais pode-se determinar a verdade dos entes em sua exatidão.

O Direito Administrativo, como todo o pensamento ocidental moderno, nasceu sob o império da representação, estruturando-se como conhecimento científico dotado de determinadas categorias matemáticas para compreender o sentido das práticas da Administração Pública, com o que seria possível atingir sua verdade. No âmbito dos princípios epocais que lhe estruturam busca-se, cada vez mais, até mesmo como modo-de-ser necessário para ultrapassar a irracionalidade absolutista, um grau de certeza e precisão, além da forma de apreender o real. Portanto, vale mencionar a sempre atual sentença de Martin Heidegger, um dos maiores filósofos do século XX: o pensamento moderno não apenas deixou de colocar a questão da verdade do ser como ainda a obstruiu. ${ }^{17}$

Há, portanto, uma índolejusracionalista preponderante no movimento revolucionário de 1789, aliada a uma concepção de direito natural, impri-

\footnotetext{
${ }_{16}^{6}$ Cf. MICHELAZZO, José. Do Um como Princípio ao Dois como Unidade, p. 41.

17 Mas, não se pode deixar de reconhecer, a metafísica também constitui-se em uma maneira do Ser acontecer. No entanto, como desconhece a diferença ontológica, acaba determinando o esquecimento do Ser, entificando-o. A razão moderna do Direito Administrativo, como já aludido, dentro de sua ânsia de ultrapassar a insegurança do período anterior, estruturou-se fundada na primazia do método por cima do ente, como mencionava Heidegger, ao criticar as ciências modernas (La Época de La Imagen Del Mundo. In: Caminos de Bosque, p. 70. Madrid: Alianza Editorial, 1998). Desta forma, somente poderia

A \& C R. de Dir. Administrativo e Constitucional, Belo Horizonte, ano 4, n. 18, p. 107-145, out./dez. 2004
} 
mindo caráter formalista e sistematizador ao Direito Administrativo, mas que foram determinantes para que a burguesia da época pudesse ascender ao poder e, ao mesmo tempo, consolidar seus ideais liberais. De qualquer sorte, o caráter ambivalente da Revolução Francesa reside em que assim como criou as condições de possibilidade para o Direito Administrativo ser o que é, desvelando o novo, foi, também, determinante para o seu velamento pelo excessivo racionalismo. Tal afirmação não apresenta qualquer problema para os fins desta pesquisa, pois seria pura ingenuidade pensar que o novo modo de existir, propiciado pela Revolução Francesa, fosse capaz de permanecer incólume à temporalização do compreender.

\subsection{Do caráter de acessoriedade (hermenêutica) dos princípios} (da Administração Pública) para a racionalidade metodológica

Os princípios jurídicos, atualmente, constituem-se em objeto de diversas teorizações dogmáticas, sendo que para alguns há uma nova "idade de ouro dos princípios", não apenas no âmbito da Filosofia do Direito, como da própria Ciência Jurídica. ${ }^{18}$ A existencialidade histórica do Direito demonstra que durante muito tempo a temática referente aos princípios ocupou os debates entre juristas e operadores jurídicos, iniciando-se com as concepções jusnaturalistas, segundo as quais os princípios jurídicos eram compreendidos como verdadeiros axiomas, portadores de verdades morais inquebrantáveis. Não tardou em consolidar-se a migração dos princípios para os sistemas codificados, adotando-se uma dimensão jusprivatista, mas com reconhecido caráter normativo, muito embora ainda legitimados como fonte subsidiária do Direito. Finalmente, faz-se mister referir o fenômeno do constitucionalismo, determinante para a inserção de princípios nos textos constitucionais, passando-se a falar em "pós-positivismo", concepção dotada de uma positividade mais de caráter aberto e axiológico, calcada nas grandes constituições do século XX. ${ }^{19}$ Considerando este horizonte de sentido, afirma Eros Roberto Grau:

Penso restar demonstrado, nestas condições, que os princípios jurídicos, todos eles, consubstanciam espécies do gênero "norma jurídica”. A circunstância de carecerem de concretização através da edição de uma regra jurídica — regra que

surgir um Direito Administrativo objetificado, um ente que pudesse ser colocado diante do homem com segurança, de forma calculada, a fim de que se alcançasse a certeza.

${ }^{18} \mathrm{Cf}$. SANCHÍS, Luis Prieto. Sobre Principios y Normas: Problemas del Razonamiento Jurídico. Madrid: Centro de Estudios Constitucionales, 1992, p. 17.

19 Sobre a expressão "pós-positivismo" e sua significação, ver BONAVIDES, Paulo. Curso de Direito Constitucional. 6. ed. São Paulo: Malheiros, 1996, p. 260-265; ALEXY, Robert. Teoria de Los Derechos Fundamentales. Centro de Estudios Constitucionales, 1997, p. 74 e OLIVEIRA, Fábio Corrêa Souza de. Por uma Teoria dos Princípios. Os Princípio Constitucional da Razoabilidade. Rio de Janeiro: Lumen Juris, 2003, p. 63.

A \& C R. de Dir. Administrativo e Constitucional, Belo Horizonte, ano 4, n. 18, p. 107-145, out./dez. 2004 
há de ser editada, em última instância, pelo juiz, em sentença, na criação de norma individual - do gênero não os exclui. Beneficiados por objetividade e presencialidade normativa que os dispensam de estarem consagrados expressamente em qualquer preceito particular as expressões são do Canotilho [1983: 199-200] —, seu caráter normativo e sua inserção no direito positivo resultam inquestionáveis. ${ }^{20}$

O Direito Administrativo Francês, até mesmo como resultado do que foi mencionado no item anterior, exerceu grande influência sobre o modo de compreensão teórica dos princípios reguladores do regime da Administração Pública, recepcionando as concepções até então existentes, em especial oriundas do jusprivatismo, sobre o caráter normativo dos princípios jurídicos. Destarte, tais elementos normativos são acolhidos a partir de um objetivo de sistematizar a atividade administrativa, fruto do ideal revolucionário fundado na concepção natural-racionalista. Os princípios, assim, ocupam papel de destaque, pois funcionalizados como elementos para esclarecer o sentido de uma norma a ser aplicada pelo Executivo ou desvendar-lhe a verdadeira "ratio". É interessante ressaltar como a idéia de legalidade influenciou o imaginário dos juristas franceses relativamente ao tema dos princípios, restando permeada pela ideologia do formalismo, isto é, por intermédio da submissão do juiz ao texto de lei, buscava-se dar a aparente neutralidade política aos poderes que aplicavam o Direito. Muito embora a recepção hermenêutica dos chamados "princípios gerais do Direito" no regime administrativo francês, inicialmente, tenha provocado mudanças na própria idéia de legalidade, acabou prevalecendo um pendor dogmáticometafísico. O Conselho de Estado, grande responsável pela estruturação normativa do conjunto de limites e prerrogativas da Administração Pública, no início de sua atuação, considerando a quase inexistência de leis regulando o agir administrativo, viu-se obrigado a formular regras que correspondiam a verdadeiros princípios gerais. No entanto, com a incorporação gradativa de tais princípios à legislação, passaram a ser utilizados dentro de uma perspectiva hermenêutico-exegética, como elementos retirados por meio de um processo de subsunção de determinados textos legais, abandonando-se o entendimento segundo o qual tais elementos normativos eram criados pelo juiz. ${ }^{21}$

Como corolário, a postura hermenêutica dos operadores do Direito em relação à aplicação dos princípios ao regime da Administração Pública,

\footnotetext{
${ }^{20}$ Ensaio e Discurso sobre a Interpretação/Aplicação do Direito. São Paulo: Malheiros, 2002, p. 149.

${ }^{21}$ Ver críticas feitas por DUPUIS, George. Droit Administratif, p. 119.
}

A \& C R. de Dir. Administrativo e Constitucional, Belo Horizonte, ano 4, n. 18, p. 107-145, out./dez. 2004 
permaneceu impregnada do que Manuel Calvo García chamou de "utopia jurídica iluminista", ${ }^{22}$ isto é, eles são utilizados como elementos que buscam preservar a generalidade e univocidade do sistema jurídico-administrativo, cujo labor é compreendido como trabalho de exegese, olvidando-se o aspecto de criação de sentido, mas, no máximo, um resgate via princípios de alguns postulados ficcionais como "vontade do legislador", "significado objetivo do sistema", etc. ${ }^{23}$

No âmbito do Direito Administrativo pátrio, pode-se dizer, muito embora preciosas tentativas de ultrapassar as posturas típicas de um positivismo estatalista, construído a partir da idéia de verdade como "adequatio res intellectus", prevaleceu um modelo formalista, ${ }^{24}$ direcionado para a necessidade de definir com conceitos plenos o que seriam os princípios da Administração Pública. Assim, tais elementos normativos são compreendidos como regras despidas de temporalidade e retiradas da historicidade, mas de observância obrigatória para construir um ideal de "bom administrador", sendo que os atos administrativos devem estar submetidos a estes padrões normativos que são verdadeiros fundamentos e sustentáculos da atividade pública. Os princípios administrativos são compreendidos como proposições básicas que alicerçam os vários setores da disciplina, institucionalizando uma espécie de fundamento último, objetificado.

Desta forma, para alguns doutrinadores há um certo senso comum segundo o qual os princípios da Administração Pública possam funcionar, "per si", como instâncias de racionalidade, vale aludir, racionalidade muito mais formal do que material, para utilizarmos a diferenciação de Max Weber, ${ }^{25}$ empreitada esta que, em última análise, não se logrou exitosa. A referência a este autor, apenas, tem por objetivo ressaltar, no âmbito do Direito Administrativo, os limites de um compreender dogmático preocupado com a busca insana de objetividade no conhecimento, especialmente fundada na matriz juspositivista, como se houvesse a possibilidade, através da construção

\footnotetext{
${ }^{22}$ Los Fundamentos del Método Jurídico, p. 90.

${ }^{23} \mathrm{Cf}$. GARCIA, Manuel Calvo. Los Fundamentos del Método Jurídico, p. 95. Para este autor a referência às ficções hermenêuticas como a "semântica da vontade" possibilita mascarar uma intervenção prática do intérprete na aplicação da lei como se fosse uma atividade meramente formal. Desta forma, estariam sendo excluídos, ao menos sob o ponto de vista ideológico, elementos materiais que pusessem em perigo a autonomia e a neutralidade na aplicação do Direito.

${ }^{24}$ Entende-se como concepção formalista do Direito (Administrativo), a construção de uma dogmática estruturada nos seguintes postulados: 1) primado da lei, enquanto regra geral, abstrata e universalmente obrigatória, que faz com que o direito repouse sobre um campo virtual; 2) representação da atividade do juiz meramente como tarefa do conhecimento da lei, portanto exegética, que faz com que a interpretação se dê independentemente do problema; 3) separação radical entre os conceitos de "interpretação" e 29. "criação" do direito. Tais características são referidas por LAMEGO, José. Hermenêutica e Jurisprudência, p.

${ }^{25}$ WEBER, Max. Economia y Sociedad. 12. reimp. Trad. por José Medina Echavarría. México: Fondo de
}

A \& C R. de Dir. Administrativo e Constitucional, Belo Horizonte, ano 4, n. 18, p. 107-145, out./dez. 2004 
racional de princípios, estruturar um ramo do Direito com uma base demonstrativa e um aparato conceitual capaz de fornecer a verdadeira interpretação racional do fenômeno administrativo.

Diretamente relacionada com este aspecto reside a quase predominante compreensão dos princípios da Administração Pública dentro de um viés sistemático, como se fossem a encarnação de uma "ratio" capaz de conferir unidade e harmonia ao sistema jurídico. ${ }^{26}$ Não se pode olvidar, nesta racionalidade há, como característica, a permanente tentativa de domínio da realidade. Os princípios da Administração Pública, por vezes, são tomados como elementos normativos aptos para a obtenção da "resposta correta". ${ }^{27}$ No entanto, este objetivo não repousa em bases teóricas convincentes, até porque não há a problematização doutrinária no âmbito do Direito Administrativo de um eventual procedimento controlado racionalmente para aplicação dos princípios do regime jurídico-administrativo, dentro de uma perspectiva de racionalidade formal. Ademais, há uma construção dogmáticaobjetificante relativamente aos conteúdos de tais espécies de normas, a fim de mascarar uma certa racionalidade material, isto é, uma aplicação dos princípios destituída de apreciações valorativas concretas de índole política, social, econômica, ética, etc., mas por intermédio de pautas gerais subsumidas a um caso concreto, sendo que o máximo admitido consiste na aplicação de teorias concebendo os princípios como "mandados de otimização" ou que não incidem na base do "tudo ou nada", que possuem uma "dimensão de peso", etc., mas sempre, com tais elementos metodológicos objetivando resgatar uma racionalidade formalista.

Inicialmente, deve-se dizer, as condições de possibilidade para maior efetividade dos princípios constitucionais, bem como a resolução dos complexos problemas gerados pelo Estado Democrático de Direito, não passam pela construção de "procedimentos racionais" ou "objetivamente controlados”, mas, sim, primeiro, pelo dar-se conta da base metafísica presente

\footnotetext{
${ }^{26}$ Cf. ROCHA, Cármen Lúcia Antunes. Princípios Constitucionais da Administração Pública, p. 24. A concepção de sistema pode ser tida como um sentido de compreensão típica da modernidade, através da necessidade de encontrar fórmulas racionais para explicar o mundo, tendo aparecido no século XVII como noção estruturadora da ciência jurídica, cf. PUCEIRO, Enrique Zuleta. Paradigma Dogmatico y Ciencia del Derecho, p. 160. Muito embora tenha havido por parte da doutrina administrativista uma certa recpção da idéia de sistema aberto, mais afeta, por exemplo, à concepção de Canaris, como uma rede axiológica — cf. FREITAS, Juarez. O Controle dos Atos Administrativos e os Princípios Fundamentais, p. 49 - há um esquema de inteligibilidade marcado pela síntese e dedução.

${ }^{27}$ Cf. HARGER, Marcelo. Reflexões Iniciais sobre o Princípio da Eficiência. RDA, Rio de Janeiro, n. 217, p. 151156, p. 152. NOBRE JR., Edilson Pereira. Princípios Retores da Desapropriação. RDA, Rio de Janeiro, n. 209, p. 121-141, jul./set. 1997. PEIXINHO, Manoel Messias. Princípios Constitucionais da Administração Pública. In: Os Princípios da Constituição de 1988, p. 447-474. Rio de Janeiro: Lumen Juris, 2001, p. 447-474.
} 
no Direito Administrativo, além de outros aspectos de aprofundamento crítico-filosófico. De qualquer sorte, o que acima foi mencionado pode ser melhor constatado no discurso de funcionalidade principiológica que tem sido desenvolvido, buscando-se nos princípios da Administração Pública a instância definitória dos diversos institutos jurídicos do Direito Administrativo ou, ainda, material normativo para o controle dos atos administrativos. Estas normas jurídicas estariam impregnadas, de forma ínsita, de valores que possibilitam uma maior objetivação da atuação do Poder Público que deve orientar-se por estas pautas, no intuito de dar a chamada "solução ótima", não podendo o agente público desviar-se da finalidade contida no texto legal e que pode ser obtida através de um procedimento de constatação.

Constitui-se esta postura teórica resultado do que Enrique Zuleta Puceiro chamou de "princípio de certeza", ou seja, a adoção de uma determinada alternativa epistemológica tem por objetivo possibilitar a promessa do conhecimento certo e objetivo, "capaz de asegurar, no solamente la validez trans-subjetiva de sus proposiciones, sino también la possibilidad de garantizar a través de sua aplicación la primacía de la seguridad em las relaciones jurídicas". ${ }^{28}$ É possível sustentar, o senso comum jurídicoadministrativo, ao recepcionar a teoria dos princípios, especialmente em decorrência da positivação dos princípios nos textos constitucionais, permaneceu atrelado a uma vetusta concepção do jurídico, consubstanciada nos procedimentos de natureza lógico-abstrata, ${ }^{29}$ sem teorizar o próprio modo-de-ser deste conhecimento. Aliás, a grande questão está no dar-se conta de que a aplicação dos princípios constitucionais não remete para o problema metodológico, mas antes trata-se de uma questão ontológica. 20 novo significado para o "compreender" dos princípios

\footnotetext{
28 PUCEIRO, Enrique Zuleta. Paradigma Dogmatico y Ciencia del Derecho, p. 195. A manifestação deste princípio, segundo o autor, pode dar-se em diversos planos, como a certeza da vigência da regra jurídica; a certeza da duração da regra relativa às garantias contra a instabilidade e a retroatividade da norma; certeza do significado da norma; certeza do comportamento pelo qual o poder é exercitado; certeza do comportamento do exercício do dever e certeza do comportamento diante do cumprimento de uma obrigação.

${ }^{29}$ São interessantes as observações de LAMEGO, José. Hermenêutica e Jurisprudência, p. 91-92 quando aduz que a recepção das teses da hermenêutica filosófica, pela jurisprudência, necessitaria, antes, uma fundamentação filosófica para os procedimentos da prática judicial e da atividade jusdogmática. Tais conclusões são preciosas para a dogmática do regime jurídico-administrativo, considerando que a teorização dos princípios constitucionais da Administração Pública não foi acompanhada por uma filosofia dos princípios, permanecendo boa parte dos juristas atrelada à metodologia juspositivista. Neste aspecto, concorda-se com BARROSO, Luís Roberto. Fundamentos Teóricos e Filosóficos do Novo Direito Constitucional Brasileiro (PósModernidade, Teoria Crítica e Pós-Positivismo). Cadernos de Soluções Constitucionais, São Paulo, n. 1, p. 150-184, 2003, p. 158, para quem "separada da Filosofia do Direito por incisão profunda, a Dogmática Jurídica volta seu conhecimento apenas para a lei e o ordenamento positivo, sem qualquer reflexão sobre seu próprio saber e seus fundamentos de legitimidade"
} 


\section{constitucionais da Administração Pública a partir da hermenêutica filosófica e da filosofia hermenêutica}

\subsection{A compreensão possui um caráter histórico}

Como condição de possibilidade para ultrapassar a objetificação dos princípios constitucionais da Administração Pública, ainda que brevemente, faz-se mister aludir o pensamento de Hans-Georg Gadamer, um dos grandes filósofos do século XX. Em uma das suas principais obras, Verdade e Método, procurou desenvolver o caráter universal da hermenêutica, no sentido de que é possível entender a verdade como um acontecer. O conhecimento é histórico porque histórico é o existente humano, assim como o mundo circundante, estando tal conhecimento submetido à estrutura do Dasein..$^{30}$ No entendimento de Gadamer, a pretensão universal da hermenêutica parte de uma experiência existencial, cujo conceito abarca o conjunto da experiência no mundo. No âmbito do Direito Administrativo, não há como construir-se uma concepção principial de regime administrativo sem uma profunda analise do próprio existir humano, daquilo que vem sendo experenciado como compreender jurídico. As grandes dificuldades de superar os postulados lógico-formais que engendraram a idéia de Administração Pública é fruto, também, da ausência de problematização do conjunto de préjuízos que tem alimentado as construções teóricas preponderantes sobre o tema.

$\mathrm{Na}$ hermenêutica gadameriana, considerando o seu caráter experencial, qualquer afirmação deve ser entendida como resposta a uma pergunta, ultrapassando-se, portanto, a "autoconsciência metodológica" que tanto tem predominado nas chamadas ciências do espírito. ${ }^{31}$ É importante salientar, a experiência gadameriana é, sobretudo, participação no sentido, ou seja, com tal indicação não se busca construir critérios absolutos de verdade, mas antes, indagar sobre o papel da experiência ontológica, vivida no encontro do intérprete - no caso operador do Direito - com os entes do mundo da vida. ${ }^{32}$ Tal horizonte de sentido vai ser fundamental para

\footnotetext{
${ }^{30}$ Cf. FERNANDEZ-LARGO, Antonio Osuna. La Hermenéutica Jurídica de Hans-Georg Gadamer. Valladolid: Secretraria de Publicaciones, Universidad, D. L., 1992, p. 45. Aqui, como em outros aspectos, é nítida a influência do filósofo Martin Heidegger, professor que foi de Gadamer. A crítica gadameriana aos métodos, como a seguir será examinada, também decorre da postura hermenêutica heideggeriana de ultrapassar a compreensão como relação sujeito-objeto para a compreensão a partir da relação sujeitp-sujeito.

31 DUTT, Casten. En conversación com Hans-Georg Gadamer. Hermenéutica/Estética/Filosofia practica, p. 29. Hans-Georg Gadamer em entrevista concedida a DUTT menciona que o conceito de método, como instância legitimadora das chamadas ciências do espírito, é inadequeada. Completando tal afirmação, aduz que as ciências do espírito teriam por característica pertencerem ä transmissão hereditária da filosofia, apresentando notas diferenciadoras em relação às ciências da natureza, desde seu modo de proceder a investigação até mesmo na relação com as coisas e sua participação na tradição.
} 
fundar uma nova ontologização dos princípios constitucionais da Administração Pública, quer dizer, uma construção teórica capaz de adentrar no campo do pensar objetificante que hodienamente tem preponderado nos processos de aplicação de tais entes jurídicos, como se fosse possível cada operador revelar, metodologicamente, a única possibilidade de sentido.

Como condição fulcral para resgatar esta mudança de perspectiva no Direito Administrativo, faz-se mister indagar como o operador do Direito pode liberar-se das inibições do modelo cientificista de verdade, na medida em que proceder a compreensão de um ente jurídico - no caso princípios constitucionais da Administração Pública - inexoravelmente passa por uma atividade do que Gadamer denominava de "projetar-se", considerando aparecer um primeiro sentido e o intérprete em seguida projetar um sentido do todo. Logo, para o autor, não há uma leitura inicial desvinculada e isolada do todo da compreensão. O sentido principiológico, poder-se-ia dizer, tão somente manifesta-se porque o intérprete já faz a leitura do texto-princípio desde determinadas expectativas significativas. Trata-se, portanto, de elaborar um projeto prévio e que vai sendo constantemente revisado. ${ }^{33}$

A partir de tais afirmações, é possível sustentar que o projeto de Gadamer ultrapassa a compreensão meramente epistemológica para (re) localizá-la na esfera do Ser. É claro, esta descrição é um tanto quanto simplista, pois toda revisão do primeiro projeto leva à possibilidade de antecipar um novo projeto de sentido. A interpretação, com efeito, começa sempre com conceitos prévios que tendem a ser substituídos progressivamente por outros mais adequados. Este constante reprojetar é que constitui o movimento do sentido do compreender e interpretar ao qual referia-se Martin Heideger.

A historicidade que há de estar presente em todo o compreender permite detectar a finitude do conhecimento e que a existencialidade constitui-se em um constante projetar de possibilidades de sentido. A compreensão, como autêntico acontecer da coisa, mostra-se capaz de detectar os diferentes modos de entender os princípios constitucionais da Administração Pública, que não possuem um aspecto de definitividade, sob pena de privar o seu acontecimento temporal. O tempo manifesta-se

\footnotetext{
32 Sobre tal tema, ver FLICKINGER, Hans-Georg. Da Experiência da Arte à Hermenêutica Filosófica. In: Hermenêutica Filosófica: nas Trilhas de Hans-Georg Gadamer. Porto Alegre: EDIPUCRS, 2000, p. 31.

${ }^{33}$ Cf. GADAMER, Hans-Georg. Verdad y Método I. Fundamentos de una hermenéutica filosófica. 5. ed. Salamanca: Sigueme, 1993, p. 332-333.
} 
como condição de possibilidade de uma compreensão diferente, não apenas para a própria coisa compreendida, mas também para o intérprete que está constituído historicamente. A distância histórica, desta forma, apresenta-se como elemento do acontecer da coisa, importante para resolver uma das questões fulcrais da hermenêutica, qual seja, fazer a distinção entre préjuízos autênticos dos pré-juízos inautênticos. Na hermenêutica gadameriana, a ausência de consciência histórica representa a incapacidade de vislumbrar esta espiral do acontecer da tradição.

Segundo Gadamer, toda compreensão da tradição opera o momento da "história efeitual", ${ }^{34}$ ou seja, para o filósofo, a chamada consciência histórica efeitual propicia o dar-se conta da história não apenas como instância de sentidos passados, previamente dados, mas como condição produtiva do ato de entender e guardião do $\operatorname{Ser}^{35}$ Daí a necessidade de construir no âmbito do Direito Administrativa a compreensão principial a partir da consciência histórica, constituindo-se como elemento fundamental para possibilitar a compreensão autêntica, apresentando-se como antítese do pensamento dogmático, objetificante e esquecido da finitude de todo compreender. A compreensão dos princípios constitucionais da Administração Pública é um processo histórico-efeitual, quer dizer, o intérprete, em sua relação com os princípios — a coisa mesma heideggeriana —, está determinado pelos fatores históricos, como salienta Gadamer.

\subsection{A compreensão não depende de métodos e o problema da técnica}

Muito embora reconheça-se a importância representada pela "recepção hermenêutica" dos princípios constitucionais na construção normativa do regime administrativo, é preciso evidenciar as insuficiências da compreensão fundada no método como instância legitimadora de sua aplicação. O trabalho desenvolvido por Hans-Georg Gadamer em

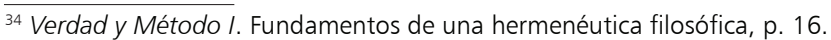

${ }^{35}$ Cf. ALMEIDA, Luís Silva de. Hermenêutica e Dialética: dos Estudos Platônicos ao Encontro com Hegel, p. 276: "Para ele, a história não é um depósito de acontecimentos passados, completados e canonizados e, conseqüentemente, não há sentido autêntico já dado de uma vez para sempre, que precise ser passivamente descoberto. Pelo contrário, a consciência histórica é a dimensão sempre crítica da hermenêutica, que entende a história como processo contínuo e sempre influente, que jamais se cristaliza num passado distante e fechado. A consciência histórica é guardião do Ser que sempre precisa ser compreendido; nela se apreende a própria consciência da finitude". Partindo-se de tal afirmação, há uma nítida influência de Heidegger, que tantas vezes afirmou o caráter de finitude da compreensão. Quando se fala em consciência histórica não se pode adotar a posição objetivista ou coisificadora, pretendendo reduzi-la a algo a ser apreendido, a história é um todo a ser renovado em cada momento do existir do Dasein, um feixe de sentidos que se deu, que possibilita a compreensão no presente e continuará sua marcha temporal no rio de sentido que é a história.
} 
Verdade e Método apresenta-se como a defesa de uma concepção do processo compreensivo do conhecimento, partindo-se do pressuposto segundo o qual nunca pode-se lograr segurar definitivamente seu objeto, pois segundo o filósofo "sempre chegamos demasiadamente tarde quando tratamos de compreender e submeter a um método aquilo que realmente entendemos". ${ }^{36}$ Ademais, o labor hermenêutico tem um caráter de paradoxal, considerando que se busca estabelecer uma aproximação com aquilo que deixa perdido, pois a tarefa do compreender não pode ser orientada por um pressuposto objetificador, bem ao gosto de uma postura cartesiana das ciências metódicas. Pelo contrário, vai salientar Jean Grondin, o aprofundamento dos estudos hermenêuticos determina o lançar do homem na esfera "da insondabilidade de qualquer experiência”.

Compreender/aplicar os princípios constitucionais da Administração Pública, desta forma, há de levar em consideração que a questão principal do problema não diz respeito a

\begin{abstract}
...averiguar el último fondo del entender, porque esto delataria más bien la obsesión cartesiana de las ciências metódicas, contra las que precisamente quiere poner en guardiã esta obra, con su título que recuerda a Goethe. Al contrario, se trata de tomar conciencia de la insondabilidad de cualquier experiência. Una experiencia hermenéutica no es algo que podemos planear y controlar en un laboratorio, sino que nos sucede, nos derrumba y obliga a pensar de otro modo. ${ }^{37}$
\end{abstract}

Aqui afigura-se um aspecto central de uma hermenêutica principial para fazer acontecer um regime administrativo autêntico: o tomar consciência de que tal compreender obriga o operador do Direito a pensar de outro modo. O homem compreendedor, como sujeito intérprete que é, possuindo Dasein, para fazer referência a Heidegger, está sempre inserido na história, rodeado por influências capazes de abrir determinadas perspectivas e horizontes do entender, mas que, ao mesmo tempo, igualmente, são responsáveis pela redução de possibilidades.

Um dos problemas da teorização tradicional da hermenêutica dos princípios constitucionais da Administração Pública reside, exatamente, em ser dominada excessivamente pela idéia de um procedimento, de um método, ${ }^{38} \mathrm{em}$ que pese sequer ter logrado a construção, por exemplo, de

\footnotetext{
${ }^{36}$ Cf. GRONDIN, Jean. Hans-Georg Gadamer. Una biografia, p. 375.

${ }^{37}$ Cf. GRONDIN, Jean. Hans-Georg Gadamer. Una biografia, p. 376.

${ }^{38}$ Cf. ALMEIDA, Custódio Luís Silva de. Hermenêutica e Dialética: dos Estudos Platônicos ao Encontro com Hegel, p. 360.
}

A \& C R. de Dir. Administrativo e Constitucional, Belo Horizonte, ano 4, n. 18, p. 107-145, out./dez. 2004 
um "método" para a aplicação de tais entes jurídicos. Portanto, a crítica aqui construída relaciona-se muito mais com uma atitude animando o imaginário dos operadores do Direito do que com relação a alcançar, efetivamente, tal desiderato. No entendimento de Casten Dutt, fazendo alusão ao pensamento de Gadamer, ${ }^{39}$ as chamadas ciências do espírito, onde pode incluir-se o Direito, dizem respeito a uma reflexão que vai mais além da auto compreensão metodológica. É preciso salientar, a concepção hermenêutica deste filósofo possui o que Jean Grondin nominou de "virtude da modéstia hermenêutica", constituindo-se um alerta contra a arrogância da pretensão de se objetivar ultrapassar a finitude do compreender, postura típica da ciência moderna e que "ameaça converter-se no novo ídolo de nossa civilização". ${ }^{40}$

Tal postura de estranhamento, direcionada para o papel das ciências modernas, não impediu a Gadamer, assim como Heidegger, reconhecerem os benefícios advindos do conhecimento científico. No entanto, as restrições direcionam-se contra a fascinação provocada por ele, até porque a postura metodológica abarca uma parcela ínfima de nossa experiência. Neste aspecto, sempre é útil fazer menção a um texto deste último filósofo, intitulado $A$ Pergunta pela Técnica ${ }^{41}$ no qual inicia procedendo um chamamento para a importância de bem compreender o significado do perguntar: "perguntar es estar construyendo un camino. Por ello es aconsejable fijar la antención en el camino y no estar pendiente de frases y rótulos aislados. El camino es un camino del pensar". ${ }^{42}$ Infelizmente, tem-se olvidado tal observação, pois via de regra lança-se um olhar quase que exclusivo sobre a importância dos conceitos, enunciados e hábitos lingüísticos, como única possibilidade de fazer acontecer os princípios constitucionais da Administração Pública. O receio de não lograr êxito no projeto científico que está na sua base, qual seja, construir este ramo do Direito como "verdadeira ciência”, dotado de "autonomia”, levou à idealização do Direito Administrativo com uma "redução dogmatista", melhor dizendo, um conhecimento direcionado para laborar apenas e tão-somente com questões tidas como "técnicas".

Do que acima restou explicitado, decorrem as grandes dificuldades do senso comum teórico, de cariz formalista, para compreender — hermeneuticamente — os entes princípios, pois o pensar tecnificante que alimenta

\footnotetext{
${ }^{39}$ En Conversación con Hans-Georg Gadamer. Hermenéutica/Estética/Filosofia Práctica, p. 30-31.

${ }^{40}$ Cf. GRONDIN, Jean. Hans-Georg Gadamer. Una biografia, p. 376.

${ }^{41}$ La Pergunta por la Técnica. In: Conferencias y Articulos. Barcelona: Ediciones del Serbal, 1994, p. 9-37.

42 "La Pergunta por la Técnica", p. 9.
}

A \& C R. de Dir. Administrativo e Constitucional, Belo Horizonte, ano 4, n. 18, p. 107-145, out./dez. 2004 
o habitus do jurista moderno impede o acontecer principial, ou seja, aquele desvelamento capaz de fazer com que um ente jurídico-administrativo possa ser-com-os-princípios-constitucionais-no-Estado-Democrático-de -Direito. No texto antes referido, Martin Heidegger menciona que a técnica ameaça não apenas o homem, mas sobretudo a verdade e o desvelamento do próprio sentido (ser). Para o filósofo, o domínio da estrutura do dispositivo - Gestell - ameaça com a possibilidade de que ao homem possa ser negado entrar em um fazer sair o oculto mais originário, sendo-lhe retirada a possibilidade de experienciar a exortação de uma verdade mais inicial. ${ }^{43}$ A técnica é a época do extremo esquecimento do ser.

\subsection{A importância da linguagem na compreensão}

Considerando que o modo-de-ser da metafísica moderna, responsável pelo enclausuramento da compreensão dos princípios constitucionais da Administração Pública acha-se excessivamente tecnificado, como criar condições de possibilidade para desvelar tais entes a partir do horizonte do Estado Democrático de Direito? Aqui afigura-se fundamental detectar a importância da linguagem, na medida em que ela ocupa papel central na concepção gadameriana, constituindo-se o acontecer lingüístico como o modo de ser da compreensão. A linguagem, assim, não mais é vislumbrada como algo que apenas veicula um conjunto de mensagens a serem posteriormente compreendidas. No caso específico desta pesquisa, o processo hermenêutico para fazer acontecer os princípios da Administração Pública mostra-se como essencialmente lingüístico, até porque o operador do Direito não tem acesso direto às coisas do mundo jurídico, mas somente na linguagem. Compreender tais princípios é um ato de linguagem, razão pela qual Gadamer vai dizer que o homem participa na linguagem. ${ }^{44}$

A compreensão de um texto-princípio dá-se, portanto, na forma de uma conversação hermenêutica, na qual o operador do Direito participa do sentido do texto, não sendo crível falar em compreender um princípio como atividade de mera reconstrução da gênese do texto, segundo HansGeorg Gadamer. ${ }^{45}$ Trata-se, com efeito, de uma fusão de horizontes, realizada na forma de conversação ocorrida no âmbito da linguagem, ou seja, como alude o filósofo, "la lenguaje es el medio universal en el que se realiza la comprensión misma”. Com isto, é crível afirmar o caráter constitutivo da linguagem relativamente ao próprio existir principial, não possuindo

43 "La Pergunta por la Técnica", p. 30.

44 Verdad y Método, p. 462.

${ }^{45}$ Verdad y Método, p. 466

A \& C R. de Dir. Administrativo e Constitucional, Belo Horizonte, ano 4, n. 18, p. 107-145, out./dez. 2004 
mera função instrumental. Aliás, as coisas do mundo jurídico, poder-se-ia dizer, ocorrem no modo de ser linguagem. A compreensão dos princípios constitucionais da Administração Pública, que é sempre interpretação, ocorre neste medium da linguagem e, para Hans-Georg Gadamer, "es una verdadera relación vital histórica, que se realiza en el medio del lenguaje y que también en el caso de la interpretación de textos podemos denominar 'conversación'. La lingüisticidad de la comprensión es la concreción de la conciencia de la historia efectual". ${ }^{46}$

O caráter constitutivo da linguagem determina o próprio pensar principiológico, sendo a este inerente, mostrando-se inadequado compreendê-la como mera ferramenta, no sentido de ser portada quando útil e deixada de lado após o seu uso. Na experiência hermenêutica dos princípios constitucionais da Administração Pública, não há como separar-se linguagem de conteúdo, como se fosse dado, primeiro, por exemplo, construir o conteúdo de interesse público, para após transmiti-lo por intermédio da linguagem. No conteúdo dado lingüisticamente já há sempre a concepção de mundo e linguagem do intérprete, pois “el lenguaje no es sólo una de las dotaciones de que está petrechado el hombre tal como está en el mundo, sino que él se basa y representa el que los hombres simplemente tengan mundo. Para el hombre el mundo está ahí como mundo...". ${ }^{47}$

Por óbvio, neste breve ensaio não se busca esgotar todas as ricas possibilidades do pensamento gadameriano para uma melhor compreensão dos princípios constitucionais da Administração Pública. No entanto, deve-se ressaltar outro elemento importante no pensamento deste autor: a finitude como característica da experiência lingüística. Tal caráter decorre da própria condição da linguagem em constante formação e desenvolvimento e é fundamental para deixar de vislumbrar nas palavras uma relação de essência relativamente às coisas que designa, bem como não é crível compreendê-las a partir de uma linguagem matemática, capaz de construir um universo objetivado e disponível pelo cálculo. Quando o pensar tecnificante indica o conteúdo de um conjunto de princípios, portanto, tal herança da tradição há de ser compreendida como possibilidade de sentido, construída lingüisticamente no âmbito de um determinado horizonte histórico. Tradição esta, por certo, que não deve simplesmente ser ignorada, mas vislumbrada como um acontecer que não cessa, mas que a cada momento é ampliada por aquele que a recebe. Em toda compreensão principial haveria uma comu-

\footnotetext{
$\overline{46}$ Verdad y Método, p. 467-468.

47 Verdad y Método, p. 531.
}

A \& C R. de Dir. Administrativo e Constitucional, Belo Horizonte, ano 4, n. 18, p. 107-145, out./dez. 2004 
nicação lingüística entre presente e tradição, responsável pelo acontecer hermenêutico, ou seja, a ação das coisas mesmas. ${ }^{48}$ Fazer a coisa acontecer não reside em aceitar simplesmente aquilo que chega por uma dada tradição, um conjunto de idéias e opiniões revestidas de naturalidade - o habitus dogmaticus no Direito Administrativo. O pensar hermenêutico é àquele dotado de caráter especulativo, contrário à posição do dogmatismo, não se entregando direta e acriticamente ao conjunto de posições dominantes, destacando-se antes pelo seu aspecto de saber refletir, como alude HansGeorg Gadamer. A linguagem da poiesis, aquela que cria o novo, o inédito, é que possibilitará o autêntico acontecer dos princípios constitucionais da Administração Pública, uma linguagem assumindo-se como instauradora de mundo, e não fundada no labor de reprodução de um algo previamente fixado. Aqui manifesta-se em toda a sua plenitude o acontecer lingüístico, via necessária para a experiência hermenêutica principial, não se podendo deixar de mencionar a famosa frase de Gadamer: "Ser que pode ser compreendido é linguagem". 49

\section{A Applicatio dos Princípios Constitucionais da Administração Pública}

3.10 caráter prático de toda interpretação dos princípios constitucionais da Administração Pública: ultrapassando a dicotomia questão de fato/questão de direito

Muito embora, como em outras oportunidades, reconheceu-se o grande contributo do labor doutrinário para a inserção das pautas principiológicas no Direito Administrativo, evidenciando, ainda mais, as insuficiências teóricas do pensamento lógico-formal que o alimentava, uma das grandes questões hermenêuticas que tem permanecido encoberta e até mesmo descuidada pelas teorizações tradicionais, diz respeito à aplicação dos princípios constitucionais da Administração Pública. Não se tardou em produzir abundante material teórico sobre a sua importância, caráter normativo, obrigatoriedade, etc., mas, é possível dizer, olvidou-se algo crucial para o juristas e operadores do Direito: a questão aplicativa de tais entes jurídicos. Logo, o pensamento de Hans-Georg Gadamer passa a ser fundamental, pois constituiu-se em tentativa de resgatar a importância da Applicatio

\footnotetext{
${ }^{48}$ A hermenêutica de Hans-Georg Gadamer, como já especificado, faz uma crítica à concepção tradicional de método, pois o autêntico método seria "fazer da coisa mesma", pensar a coisa em suas conseqüências, o que não poderia ocorrer com a fixação de um "caminho metodológico" a ser tecnicamente percorrido, sempre à disposição do intérprete.

${ }^{49}$ Verdad y Método I, p. 567.
}

A \& C R. de Dir. Administrativo e Constitucional, Belo Horizonte, ano 4, n. 18, p. 107-145, out./dez. 2004 
no processo de interpretação e que havia perdido-se na autoconsciência histórica da teoria hermenêutica tradicional, muito em virtude do pensamento dominante segundo o qual a aplicação de um sentido à situação presente prejudicava o ideal de objetividade da interpretação, como aduz Jean Grondin. ${ }^{50}$

Dentro de tal perspectiva gadameriana, é impositivo para a construção de uma teoria dos princípios da Administração Pública ultrapassar a visão formal que tem preponderado, segundo a qual no processo de compreensão de um princípio é possível separar, congelar os momentos que culminam na aplicação de um texto. Há, com efeito, uma integração entre o processo aplicativo e a interpretação, considerando a applicatio companheira indissociável de toda atividade interpretativa. ${ }^{51}$ Faz-se mister, portanto, recuperar seu valor hermenêutico, no caso desta pesquisa, para o Direito Administrativo, elemento este olvidado desde a hermenêutica de Schleiermacher, sendo cada vez mais importante desvelar o caráter de aplicação como a adaptação do sentido de um princípio à situação concreta de sua materialização. Para a concepção mais tradicional, o problema hermenêutico era dividido através de uma análise de três momentos distintos: a subtilitas intelligendi, subtilitas explicandi e subtilitas applicandi. No entanto, para Gadamer, a interpretação não é um ato complementar e posterior ao da compreensão, senão que compreender é sempre interpretar e, por conseqüência, a interpretação é a forma explícita da compreensão:

\begin{abstract}
Sin embargo, nuestras consideraciones nos fuerzan a admitir que en la comprensión siempre tiene lugar algo así como una aplicación del texto que se quiere comprender a la situación actual del intérprete. En este sentido nos vemos obligados a dar un paso más allá de la hermenéutica romántica, considerando como un proceso unitario no sólo el de comprensión e interpretación, sino también el de la aplicación. ${ }^{52}$
\end{abstract}

Com efeito, materializar um princípio constitucional da Administração Pública exige este dar-se conta por parte do intérprete, de que não há um momento prévio de compreensão e isolado da situação ao qual ele pertence. Ultrapassa-se a vetusta dicotomia entre questão de fato e questão de direito, considerando a tensão sempre existente entre o texto do princípio a ser aplicado e o sentido por ele alcançado no momento concreto da interpretação. Ademais, no entendimento de Gadamer, cada momento Introduccion a Gadamer. Madrid: Herder, 2003, p. 159-160.

${ }^{51}$ Cf. FERNANDEZ-LARGO, Antonio Osuna. La Hermenéutica Jurídica de Hans-Georg Gadamer, p. 75.

52 Verdad y Método I, p. 378-379. Por esta razão, Gadamer vai concluir que a aplicação é um momento do processo hermenêutico tão essencial como a compreensão e a interpretação. 
de compreensão revela uma nova e diversa possibilidade de sentido do texto. Pode-se dizer, ao mesmo tempo em que um princípio possibilita expressar uma indicação, constitui-se como elemento de uma tarefa prática que é a hermenêutica jurídica, tencionando-se como o individual da situação concreta a ser compreendido. Logo, conforme Gadamer, há sempre uma condição de deficiência na lei decorrente da incapacidade de conter em si a realidade prática em toda a sua concreção. ${ }^{53}$

Não se imagine, no entanto, que o pensamento gadameriano fosse capaz de levar a um niilismo principiológico. No labor de interpretar os princípios constitucionais da Administração Pública há sempre uma relação com o conjunto de indicações postas pela tradição, relação esta que não é sempre a mesma, deixando de adquirir o contorno de um saber objetivista, até porque materializar princípios passa pela síntese entre o geral e o particular, exigindo um autêntico fazer (poiesis) por parte do operador do Direito. Trata-se de um verdadeiro acontecer, exigindo uma adaptação do geral às circunstâncias do caso concreto. ${ }^{54} \mathrm{~A}$ hermenêutica dos princípios constitucionais da Administração Pública, portanto, possui um caráter prático, considerando que o "sentido principial" somente alcança sua aplicação no momento concreto de sua aplicação, razão pela qual tais entes jurídicos são compreendidos em cada momento e em cada situação concreta de uma maneira nova. A partir da concepção teórica aqui adotada, não há como isolar o ato de conhecer o texto de um ente-princípio do ato de aplicação ao caso concreto, mostrando-se mais adequado vislumbrar como um processo unitário.

Com efeito, para Hans-Georg Gadamer, a tarefa de interpretação constitui-se em um concretar a lei em cada caso, quer dizer, na sua aplicação, cuja tarefa incumbe ao juiz que, por intermédio de uma ponderação justa do conjunto, compreende a normatividade do texto. A vinculação do juiz à lei e a proibição de não poder compreender de modo arbitrário, deve ser

\footnotetext{
53 Neste aspecto, Hans-Georg Gadamer recorre à ética de Aristóteles, pois para este filósofo, a ética humana não é mero conhecimento ou descrição dos comportamentos humanos, mas um atuar que recebe uma diretriz, acrescentando-se um juízo concreto. Sobre a questão Antonio Osuna Fernandez-Largo (La Hermenéutica Jurídica de Hans-Georg Gadamer, p. 76) menciona a aproximação entre a atividade hermenêutica e o agir ético-aristotélico, considerando que na interpretação parte-se da tradição e do texto histórico, realizando-se uma atualização na qual complementa-se e aperfeiçoa-se o dito pelo texto. Aduz expressamente: "La comprensión es el acontecer de la interpretación, como la praxis ética es el momento final de la razón ética (p. 77). Outra conseqüência direta desta similitude reside na circunstância de que o saber ético não se relaciona com a mera aplicação de uma técnica que produz artefatos, mas assim como na atividade interpretativa, possui o objetivo de perseguir uma determinada finalidade interna da pessoa, e que Aristóteles constrói a partir da idéia de bom sentido e Gadamer por intermédio da noção de juízo compreensivo (p. 78).

${ }^{54}$ Cf. GADAMER, Hans-Georg. Verdad y Método I, p. 389
} 
vislumbrada como a necessidade de validade da lei para todos, mas sem cair no pensamento segundo o qual o ato de interpretação é fruto de mera subsunção. ${ }^{55} \mathrm{O}$ compreender, desta forma, não está relacionado com um sentido a ser buscado no autor originário dos princípios constitucionais da Administração Pública, mas em a partir do texto-princípio desvelar o sentido, ou ainda, “... el texto se entiende como un documento cuyo sentido real tiene que ser elucidado más allá de su sentido literal, por exemplo, comparándolo con otros dados que permiten evaluar el valor histórico de una tradición" ${ }^{56}$ A compreensão já é uma aplicação, uma atividade concreta na qual se reconhece a consciência da história efeitual, na qual o intérprete surge como pertencente ao texto que compreende.

\subsection{O caráter circular (não linear) da interrogação dos princípios constitucionais da Administração Pública}

Um dos pressupostos para construir as condições de possibilidade de ultrapassar a concepção tradicional e racional-formal dos princípios constitucionais da Administração Pública é evidenciar o modo como se dá a compreensão, expressada no chamado círculo hermenêutico" ${ }^{57}$ Logo, o proceder da compreensão de um princípio, inexoravelmente passa por uma atividade do que Gadamer denomina de "projetar-se", considerando aparecer no texto um primeiro sentido e o intérprete em seguida projeta um sentido do todo. Não há uma leitura inicial desvinculada e isolada do todo da compreensão. No caso dos princípios constitucionais da Administração Pública, poder-se-ia dizer do modo-de-ser do Estado Democrático de Direito. Assim sendo, o sentido principial manifesta-se porque o operador do Direito já faz a leitura do princípio desde determinadas expectativas de

\footnotetext{
5 GADAMER, Hans-Georg. Verdad y Método I, p. 402. Refere Gadamer: "Claro que esta tarefa de la concreción no consiste únicamente en un conocimiento de los artículos correspondientes. Hay que conocer también la judicatura y todos los momentos que la determinan si se quiere juzgar juridicamente un caso determinado. Sin embargo, la única pertencia a la ley que aquí se exige es que el ordenamientojuridico sea reconocido como valido para todos y que en consecuencia no existan excepciones respecto a él"

${ }^{56}$ GADAMER, Hans-Georg. Verdad y Método I, p. 409.

${ }^{57}$ Gadamer toma como pressuposto a elaboração da estruturação prévia da compreensão levada a termo por Heidegger, procedendo uma recuperação da analítica do Dasein como fio condutor de uma nova interpretação, cf. ALMEIDA, Custódio Luís Silva de. Hermenêutica e Dialética: dos estudos platônicos ao encontro com Hegel. Porto Alegre: EDIPUCRS, 2002, p. 258. Por esta razão, Gadamer vai valer-se dos existenciais "projetar", "aberto", "disposto", acrescentando o sentido hermenêutico na linguagem, como entende este autor. Sobre a utilização da expressão "círculo hermenêutico", não se pode olvidar que a importância desta referência possibilita Gadamer entabular sua crítica ao chamado círculo lógico de compreensão, pois o círculo hermenêutico não remete para um procedimento demonstrativo da verdade, mas constitui-se em condição de possibilidade do compreender. Destarte, melhor seria representá-lo como um espiral e não um círculo fechado em si mesmo, cf. CORETH, Emerich. Questões Fundamentais de Hermenêutica. São Paulo: EDUSP, 1973, p. 90.
} 
sentido.

Trata-se, portanto, de elaborar um projeto prévio e que vai sendo constantemente revisado. ${ }^{58}$ Com estas afirmações, fica clara a pretensão de Gadamer de ultrapassar uma compreensão meramente epistemológica para relocalizá-la na esfera do Ser, o que pode ser plenamente construído no âmbito da aplicação dos princípios constitucionais da Administração Pública. A interpretação, com efeito, começa sempre com conceitos prévios que tendem a ser substituídos progressivamente por outros mais adequados. Este constante reprojetar é que constitui o movimento do sentido do compreender e interpretar que descreve Heidegger. ${ }^{59}$ Já, no entendimento de Gadamer, a compreensão só alcança suas verdadeiras possibilidades quando as opiniões prévias com as quais se inicia não são arbitrárias, ${ }^{60}$ mostrandose aqui fundamental a abertura ao texto, considerando que neste "aberto" procede-se o início do processo de convalidação dos juízos prévios com "a coisa mesma" que deve ser compreendida. ${ }^{61}$ Neste entender da coisa, que é um entender-se com a coisa, exige uma atitude de cautela do intérprete, não sendo dado a ele dirigir-se diretamente aos textos — no caso do Direito Administrativo textos-princípios - sem um prévio questionamento quanto à sua legitimidade e validade.

No entanto, é claro que surge a pergunta de como estabelecer esta diferenciação entre o uso lingüístico acostumado e o do texto? Gadamer menciona que, em geral, pode-se dizer que a experiência do "choque com

\footnotetext{
${ }^{58}$ Cf. GADAMER, Hans-Georg. Verdad y Método I. Fundamentos de una Hermenéutica Filosófica. 5. ed. Salamanca: Sígueme, 1993, p. 332-333.

${ }^{59}$ A concepção de círculo hermenêutico é crucial para o âmbito do Direito (Administrativo) porque remete a possibilidade de compreensão para o próprio homem, pois somente por intermédio deste é possível compreender, ou seja, pela explicitação de sua estrutura ontológica, e o operador do Direito só compreende o sentido principial porque este já o constitui (círculo). Como refere Ernildo Stein, "a compreensão que o homem tem do sentido é a de que nós só temos o sentido pela compreensão porque se realizam no ser humano duas compreensões: a compreensão de si mesmo e a compreensão do ser" (Aproximações Hermenêuticas. Porto Alegre: EDIPUCRS, 1996, p. 57).

${ }^{60}$ Cf. GADAMER, Hans-Georg. Verdad y Método I, p. 333.

${ }^{61}$ Cf. ALMEIDA, Custódio Luís Silva de. Hermenêutica e Dialética, p. 259. Sobre a coisa mesma, Gadamer, ao responder um questionamento de Jean Grondin, in: RETROSPECTIVA DIALOGICA à Obra Reunida e sua História da Efetuação, p. 209, sobre o que seria a coisa mesma mencionou: "É preciso apenas que se tenha para si, bem claro, o que a coisa propriamente significa. A coisa é sempre a coisa polêmica. E isto, enquanto seres humanos errantes, não deveríamos nunca esquecer; pois aí se funda todo o esforço de ultrapassar nosso preconceitos. A coisa mesma, Husserl chamou-a, também, o objeto intencional. E lembro-me de como Heidegger perguntava (no pro-seminário em Freiburgo) o que seria, ao fundo, o objeto intencional. E foi ele mesmo que antecipou, ousadamente, a resposta de que o objeto intencional seria o Ser obviamente, em oposição ao existente. Quando Heidegger fala da própria coisa e do fenômeno que se mostra, ele tem em mente a destruição do que encobre, e nisto está implícita toda subestrutura temporal

e histórica. O descobrir dos preconceitos, levando o Ser a mostrar-se, é uma conseqüência da análise da temporalidade em Ser e Tempo de Heidegger. Os preconceitos, à base dos quais se julga, não nos são, de modo algum, conscientes. Nessa medida, a coisa é sempre uma coisa polêmica"
} 
um texto" é o que faz com que o intérprete venha deter-se e atentar-se para a possibilidade de uma diferença no uso da linguagem. ${ }^{62}$ Este raciocínio em relação ao hábito lingüístico, também vale para as "opiniões de conteúdo" com as quais os textos são lidos e que constituem as pré-compreensões dos mesmos. Também aqui coloca-se o problema de como achar a saída do círculo das próprias posições pré-concebidas. Gadamer ainda questiona: como se pode proteger um texto previamente em relação a mal-entendidos?

Aqui mostra-se importante aludir o caráter dialógico do pensamento gadameriano. De plano, o intérprete não pode assumir uma postura isolacionista no processo de compreensão de um princípio, mas deve estar aberto para a opinião do outro ou a do texto-princípio, de modo a que seja possível estabelecer um todo relacional, no qual tais opiniões do texto são confrontadas com as próprias opiniões. Para Gadamer, o que quer compreender não pode entregar-se, desde o princípio, ao azar de suas próprias opiniões prévias e ignorar o mais obstinada e conseqüentemente possível a opinião do texto, pois

el que quiere comprender un texto tiene que estar en principio dispuesto a dejarse decir algo por él. Una conciencia formada hermenéuticamente tiene que mostrarse receptiva desde el principio para la alteridad del texto. Pero esta receptividad no presupone ni "neutralidad" frente a las cosas ni tampoco autocancelación, sino que incluye una matizada incorporación de las proprias opinioes previas e prejuicios. Lo que importa es hacerse cargo de las proprias anticipaciones, con el fin de que el texto mismo pueda presentarse en su alteridad y obtenga así la posibilidad de confrontar su verdad objetiva con las proprias opiniones previas. ${ }^{63}$

Logo, o objetivo da teorização de Gadamer não é propor evitar a presença dos juízos prévios, mas que o intérprete se dê conta do caráter de inevitabilidade, a fim de que possa percebê-los e controlá-los. Menciona o filósofo que são os preconceitos não percebidos os que, com seu domínio,

\footnotetext{
${ }^{62}$ GADAMER, Hans-Georg. Verdad y Método I, p. 334. Segundo o autor: "Y lo que afirmamos respecto a las opiniones previas contenidas en el hábito lingüístico vale también para las opiniones de contenido con las que nos acercamos a los textos y que constituyen nuestra precomprensión de los mismos. También aquí se plantea el problema de cómo hallar la salida del círculo de las proprias posiciones preconcebidas"

${ }^{63}$ GADAMER, Hans-Georg. Verdad y Método I, p. 335-336. O dar-se conta de que no entender sempre há uma pré-compreensão, constitui-se em elemento fundamental para ultrapassar o paradigma da filosofia da consciência. Outrossim, como salienta ALMEIDA, Custódio Luís Silva de. Hermenêutica e Dialética, este dar-se conta dos juízos prévios é encontrar a própria historicidade, perceber-se em uma tradição e ter consciência da finitude e "somente aí tem início o processo de compreensão do ser e a 'coisa mesma' a ser interpretada começa a se manifestar. Na relação que se estabelece entre o intérprete e o texto, os préjuízos vêm à tona; adequá-los à 'coisa mesma' é a tarefa da compreensão"

${ }^{64}$ GADAMER, Hans-Georg. Verdad y Método I, p. 336.
} 
tornam surdos os intérpretes para a coisa de que lhes fala a tradição. ${ }^{64}$ Conseqüentemente, é importante o reconhecimento do caráter essencialmente preconceituoso de toda compreensão.

A obra Verdade e Método procura reabilitar a noção de preconceito e que foi obscurecida pelo Iluminismo, sendo que Gadamer vislumbra nesta categoria a chave de todo o processo de compreensão, ou seja, uma verdadeira condição de possibilidade:

Un análisis de la historia del concepto muestra que sólo en la Ilustración adquiere el concepto del prejuicio el matiz negativo que ahora tiene. En sí mismo "prejuicio" quiere decir un juicio que se forma antes de la convalidación definitiva de todos los momentos que son objetivamente determinantes. En el procedimiento jurisprudencial un prejuicio es una predecisión jurídica antes del fallo de una sentencia definitiva. Para el que participa en el proceso judicial un prejuicio de este tipo representa evidentemente una reducción de sus posibilidades. Por eso en francés "préjudice", igual que "praejudicium", significa también simplemente prejuicio, desvantaja, daño. Sin embargo esta negativa es sólo secundaria, es la consecuencia negativa de una validez positiva, el valor prejudicial de una predecisión, igual que el de cualquier precedente. ${ }^{65}$

Melhor explicitando, Gadamer busca fazer justiça ao modo de ser finito e histórico do homem, admitindo a possibilidade de haver prejuízos legítimos.

É certo, não se desconhece que algumas construções teóricas sobre princípios, igualmente, fazem menção à idéia de círculo hermenêutico, mas denota-se uma concepção formal, quer dizer, uma relação formal entre o individual e o todo, sendo que o movimento circular da compreensão vai e vem pelos princípios e acaba superando-se na compreensão completa de tais entes jurídicos, como as tradicionais construções fundadas metafisicamente por uma interpretação sistemática, capaz de, por si, revelar a totalidade de sentido de um princípio. Heidegger, pelo contrário, descreve este círculo em forma tal que a compreensão do texto encontre-se determinada continuamente pelo movimento antecipatório da pré-compreensão. O círculo do

\footnotetext{
$\overline{65}$ GADAMER, Hans-Georg. Verdad y Método I, p. 337. Segundo OLIVEIRA, Manfredo Araújo de. Reviravolta Lingüístico-Pragmática na Filosofia Contemporânea. São Paulo: Loyola, 1996, p. 228, n. 7, "Para Gadamer, esse ponto é fundamental, pois a exigência de superação de todo e qualquer pré-conceito, que constitui o ideal do iluminismo, se revela como um pré-conceito que precisa ser questionado, a fim de abrir espaço à finitude humana. A razão só existe para nós homens, diz Gadamer, enquanto história, e isso significa dizer: ela não é simplesmente senhora de si mesma, mas depende de dados históricos. A idéia de autoconstrução absoluta da razão — o preconceito basilar do iluminismo — é também uma realidade histórica". Com efeito, considerando os pré-conceitos como realidades históricas, não há como, através de um processo de abstração, eliminá-los da compreensão mesma, sob pena de a compreensão ocorrer sem o elemento histórico. A eliminação do pré-conceito importaria em olvidar a história e a circunstância do homem como ser histórico, ou seja, um ser que se dá na histórica e somente pode ser com ela.
} 
todo e das partes não se anulam na compreensão total, senão que alcança nela sua realização mais autêntica, constituindo-se, desta forma, em um círculo ontológico-hermenêutico. ${ }^{66}$

Partindo-se de tudo que até agora restou explicitado, de como há na base do Direito Administrativo um projeto exegético, alimentado por uma razão legal, construída a partir de um paradigma liberal-individualista, bem como a necessidade de adotar-se outra compreensão relativamente ao processo de aplicação dos princípios constitucionais da Administração Pública, faz-se mister explicitar algumas, por óbvio não todas, considerando os limites deste breve estudo, projeções hermenêuticas sobre um dos grandes princípios que aparece na cotidianidade do operador do Direito, via de regra aplicado sem maiores aprofundamentos hermenêuticos: o princípio do interesse público.

\subsection{A (necessária) compreensão ponderada do interesse público: ultrapassando as dicotomias metafísicas da modernidade}

A construção da idéia de interesse público, como elemento de legitimidade do regime jurídico-administrativo, apresenta-se como tema propício para uma reconstrução a partir da matriz teórica aqui adotada. Segundo corrente na doutrina administrativista, tal princípio funciona como elemento normativo determinante da superioridade do interesse da coletividade em relação ao interesse dos particulares. Portanto, a Administração Pública figuraria nas relações com os cidadãos com uma posição privilegiada relativamente ao exercício de poderes ou a prática de atos administrativos, bem como para o ente público surgiriam determinadas limitações, como a indisponibilidade relativa dos bens públicos, a obrigação de sempre materializar o interesse da coletividade, o dever de anular atos administrativos, etc.

Ao conceituar o que seria interesse público, Héctor Jorge Escola menciona tratar-se do

\footnotetext{
66 Segundo Gadamer, "El círculo no es, pues, de naturaleza formal; no es subjetivo ni objetivo, sino que describe la comprensión como la interpenetración del movimiento de la tradición y del movimiento del intérprete. La anticipación de sentido que guía nuestra comprensión de un texto no es un acto de la subjetividad sino que se determina desde la comunidad que nos une con la tradición. Pero en nuestra relación con la tradición, esta comunidad está sometida a un proceso de continua formación. No es simplemente un presupuesto bajo el que nos encontramos siempre, sino que nosotros mismos la instauramos en cuanto que comprendemos, participamos del acontecer del la tradición y continuamos determinándolo así desde nosotros mismos. El círculo de la comprensión no es en este sentido un círculo $<<$ metodológico $>>$ sino que describe un momento estructural ontológico de la comprensión". A inter relação que se dá entre o operador do Direito e texto-princípio a ser compreendido, com efeito, opera no âmbito de uma copertença, melhor explicando, o intérprete no processo de compreender determina a configuração da coisa mesma (princípio) a partir de um conjunto de expectativas de sentido, como alude Gadamer, oriundo das pré-compreensões do sujeito com o próprio assunto em questão. Destarte, na medida em que esta relação compreensiva vai desenvolvendo-se há uma interatividade da coisa com a compreensão do intérprete e que caba, muitas vezes, por modificá-la
} 
resultado de un conjunto de intereses individuales compartidos y coincidentes de un grupo mayoritario de individuos, que se asigna a toda la comunidad como consecuencia de esa mayoría, y que encuentra su origen en le querer axiologico de esos individuos, apareciendo con un contenido concreto e determinable, actual, eventual o potencial, personal y directo respecto de ellos, que pueden reconocer en él su proprio querer y su propia valoración, prevaleciendo sobre los intereses individuales que se le opognan o lo afecten, a los que desplaza o sustituye, sin aniquilarlos. ${ }^{67}$

Tais concepções doutrinárias, inclusive, são refletidas em alguns julgados, como no caso do servidor público que buscava invalidar ato administrativo determinante de modificação na sua jornada de trabalho, não sendo acolhida sua pretensão com base no princípio em comento, cujo acórdão restou assim ementado: "ADMINISTRATIVO. SERVIDOR PÚBLICO. Jornada de trabalho previamente fixada em Decreto municipal. Ingresso na função pública quando em vigência o ato regulamentador. Insurgência do servidor público no sentido de não cumprir o horário determinado que não encontra amparo, pena de fratura dos princípios da legalidade e supremacia do interesse público. Acordo verbal que não é válido ante vínculo institucional mantido com o ente de direito público. SENTENÇA DE IMPROCEDÊNCIA DO PEDIDO. APELO DESPROVIDO”. ${ }^{68}$

Também houve a utilização da supremacia do interesse público sobre o privado para desacolher a pretensão de servidor militar que pretendia sua transferência para unidade militar diversa daquela na qual estava a exercer suas atividades, pois teria preenchido os requisitos fixados na legislação estadual sobre o tema. O Tribunal de Justiça do Estado assim decidiu: “APELAÇÃO CÍVEL. PORTO ALEGRE. POLICIAL MILITAR. TRANSFERÊNCIA. ARTIGO 18, INCISO III DO DECRETO N. 36.175/95. PARECER DESFAVORÁVEL. INTERESSE PÚBLICO. PREVALÊNCIA SOBRE O PARTICULAR. Ausente conveniência para o serviço, não tem o policial militar direito subjetivo à transferência de Batalhão. Supremacia do interesse público face ao privado. Inteligência do artigo 18 III c/c os

\footnotetext{
7 ESCOLA, Hector. El Interés Público como Fundamento del Derecho Administrativo. Buenos Aires: Depalma, 1989, p. 249-250.

${ }^{68}$ RIO GRANDE DO SUL. Tribunal de Justiça. AC nº 70003933213, TJRS, $3^{\text {a }}$ CC, Rel. Des. Augusto Otavio Stern, j. 06.06.2002.

${ }^{69}$ RIO GRANDE DO SUL. Tribunal de Justiça. AC n 70004536413 , TJRS, 4a CC, Rel. Des. Vasco Della Giustina,

j. 04.09.2002. Outras decisões sobre o tema poderiam ser citadas, a título exemplificativo, apenas no intuito

de demonstrar haver a difusão dogmática deste princípio no âmbito da jurisprudência: "Administrativo.

Processual Civil. Serrvidor Público. Gozo de Licença-Prêmio. Ato Discricionário da Administração Pública.

Conveniência e oportunidade do serviço. Princípio da legalidade. Supremacia do Interesse Público. Mandado
}

A \& C R. de Dir. Administrativo e Constitucional, Belo Horizonte, ano 4, n. 18, p. 107-145, out./dez. 2004 
artigos $1^{\circ}$, inciso $V$ e $2^{\circ}$, parágrafo único do Decreto n. 36.175/95. APELO DESPROVIDO". ${ }^{69}$

O que se pode constatar em tais decisões é a influência de uma tradição liberal-individualista na construção teórica deste princípio, importando num tratamento metafísico entre as esferas pública e privada. Não se pode desconsiderar, e este é um dos aspectos a ser cada vez mais evidenciado pela hermenêutica, que na base das compreensões dogmáticas que chegam da tradição do princípio do interesse público há um conjunto de préjuízos que, por vezes, tem levado a uma compreensão excessivamente formalista e centralizadora deste ente. Portanto, faz-se mister um labor de compreensão para suspender tais préjuízos (inautênticos) que impedem o acontecer democrático do interesse público, por exemplo, como não exclusivo do espaço público estatal.

Outro aspecto a ser evidenciado reside na visão abstrata de interesse público que acabou sendo gerada pelo pensamento fundado na metodologia lógico-dedutiva, pois interesse público passou a ser elemento axiomático e conceitual de uma racionalidade formal. Logo, permaneceu-se impregnado da já aludida "utopia jurídica iluminista", ou seja, a idéia de interesse público é construída para preservar a generalidade e unicidade do sistema jurídico-administrativo, revelado como resultado da vontade geral.

A partir da perspectiva teórica aqui adotada, não se pode deixar de considerar que compreender o princípio do interesse público é sempre um ato de linguagem, até porque tal compreensão ocorre na forma de conversação hermenêutica, não ocorrendo uma atividade de mera reconstrução da gênese dos textos jurídicos, mas o resultado da fusão de horizontes que

\footnotetext{
de Segurança. Liminar indeferida na origem. Improcedência da impetração na origem. Não provimento em grau recursal." (AC no 70002491926, TJRS, 4a CC, Rel. Des. Wellington Pacheco Barros, j. 06.06.2001). "ADMINISTRATIVO E CONSTITUCIONAL. Mandado de segurança. Licença para construir posto de combustíveis no Município de Bento Gonçalves. Exigências, pela Administração, de projeto de acessibilidade e de estudo de impacto ambiental após a aprovação do projeto. Determinação que não são contrárias à lei e que primam pelo interesse geral. Aplicação do princípio da supremacia do interesse público sobre o privado. Interpretação sistemática da legislação municipal que regulamenta a matéria. Ausência de direito líquido e certo amparável via mandado de segurança. Sentença que concedeu a ordem. Recurso de Apelação Provido. Reexame Necessário Prejudicado." (AC e RN n. 70000477869, TJRS, 3a CC, Rel. Des. Augusto Otávio Stern, 05.10.2000). "Ato Administrativo. Erro de fato que redunda em vício de legalidade e autoriza a anulação (súmula 473). retificação de enquadramento de servidora beneficiada por ascensão funcional, fundada em erro quanto à sua situação anterior. validade- O Poder de auto tutela da administração autoriza a retificação de ato fundado em erro de fato, que, cuidando-se de ato vinculado redunda em vício de legalidade e, portanto, não gera direito adquirido. Tratando-se de ato derivado de erro quanto à existência dos seus pressupostos, faz-se impertinente a invocação da tese da inadmissibilidade da anulação fundada em mudança superveniente da interpretação da norma ou da orientação administrativa, que pressupõe a identidade de situação de fato em torno do qual variam os critérios de decisão" (BRASIL. Supremo Tribunal Federal. RMS 21.259, STF, Rel. Min. Sepúlveda Pertence, j. 24.09.1991).
} 
acontece no âmbito da linguagem. Um dos grandes problemas ignorados pelo pensamento de cariz metafísico é que no conteúdo do interesse público, dado lingüisticamente, já há sempre a concepção de mundo do intérprete. Poder-se-ia dizer, gadamerianamente, não ser crível compreender o interesse público sem evidenciar a importância da applicatio. Ao mesmo tempo que a materialização do princípio em comento exige uma tarefa de diálogo com o conjunto de indícios-formais-constitucionais, ${ }^{70} \mathrm{o}$ sentido do interesse público apenas alcança sua compreensão autêntica no momento concreto de sua aplicação.

Com efeito, no Estado Democrático de Direito, a autenticidade, no sentido de desvelamento, de acontecer democrático, do interesse público, passa pela circularidade hermenêutico-constitucional, ou seja, um agir ponderativo vislumbrado como existencial que remete a compreensão para o todo de possibilidades de sentido. Neste aspecto, é importante a lição de Lenio Luiz Streck quando menciona a relação de co-pertença originária com a Constituição:

é necessário ter claro que a Constituição não é um elemento objetivo do qual se deduz outros elementos objetivos. Se assim pensássemos, a Constituição seria transformada em um elemento objetificador. Quando interpretamos um texto infraconstitucional (que é um ente no seu ser), o fazemos não deduzindo o sentido a partir de uma categoria ou substrato geral, mas sim, a partir de uma co-originariedade. Não percebemos as coisas primeiro em seu "ser-objeto". As vivências sempre se dão em um mundo circundante (Umwelt). ${ }^{71}$

Hermeneuticamente, é possível sustentar que entre interesse

\footnotetext{
70 Sobre a teoria dos indícios formais ver STEIN, Ernildo. Pensar é Pensar a Diferença, p. 159 et seq. Nesta obra o autor traz um texto fundamental para a compreensão da Teoria dos Indícios Formais, Os Indícios Formais e a Base Não-Inferencial para o Conhecimento, relatando que a introdução dos existenciais pode ser feita, exatamente, com a descrição dos indícios formais. Trata-se de um pensamento não objetificador, pois não há um universo pronto, chegando-se aos indícios formais fenomenologicamente. Descrever os indícios formais, com efeito, importa buscar as diversas características do Dasein e que revelam o próprio modo-deser-no-mundo (Id., p. 160). Assim, refere expressamente, "o existencial é posto no lugar do transcendental como elemento organizador. O existencial não é uma simples remissão ao empírico, ao existente — os espanhóis traduzem por existentivo - mas é uma dimensão que não tem justamente esse caráter de categoria, mas de qualidade existencial" (Idem, p. 160-161). A tarefa do intérprete passaria pela necessária descrição dos indícios formais como modo de chegar ao máximo número de atos exercidos e que, dentro da perspectiva fenomenológica, são as dimensões existenciais (p. 163). Vale aduzir, é imperioso para este pensar o que Heidegger chamou de educação fenomenológica, pois este exercício do descrever fenomenológico importa em possibilitar ver aquilo que normalmente está encoberto. Aqui entra em jogo o caráter ambivalente do estar encoberto e aquilo que se mostra. Segundo Heidegger, a fenomenologia é o exercício de tentar mostrar, naquilo que se mostra, aquilo que de si não se mostra e que, só num exercício de explicitação dos indícios formais, irá mostrar-se" (Id., p. 164). Este, portanto, seria o significado de ir às coisas mesmas possibilitado pela Teoria dos Indícios Formais.

71 Jurisdição Constitucional e Hermenêutica, p. 446.

${ }^{72}$ Considerando os limites deste estudo, o tema da ponderação merece uma análise específica. Devido a importância do tema para uma compreensão hermenêutica dos princípios constitucionais da Administração Pública, ver OHLWEILER, Leonel. A Ponderação no Regime Administrativo Brasileiro: Contributo da Fenomenologia Hermenêutica. Tese (Doutorado) - UNISINOS, São Leopoldo, 2003.
} 
público e constituição há uma relação de co-pertença, quer dizer, o texto da constituição não vai funcionar como elemento de subsunção, mas locus lingüístico privilegiado para permitir a necessária ponderação, ${ }^{72}$ a fim de exsurgir a unidade hermenêutica entre interesse público e privado. Muito embora não se pretenda aqui esgotar a problematização gerada por este princípio, pode-se dizer que o interesse público remete para uma indagação paradoxal de materialização da cidadania para o Estado. O que se afasta, de plano, é a concepção objetificadora, racional-formalista, para dimensionar as potencialidades do princípio em análise, isto é, não há como desvelálo no âmbito dos enunciados abstratos, sob pena de adotar uma postura entificadora, encobridora do sentido democrático de interesse público.

Efetivamente, um agir de ponderação, a partir da matriz hermenêutica aqui adotada, pode constituir-se como a via de acesso capaz de determinar a problematização não metafísica do interesse público, uma compreensão que prime pelo acontecer do interesse público no âmbito do Estado Democrático de Direito, ao invés de olvidar que qualquer princípio constitucional da Administração Pública só é, na medida em que compreendido com os demais. Exemplo de objetificação pode-se detectar no primeiro julgado referido neste item, o "Caso da Jornada de Trabalho", pois sequer ponderou-se o interesse público com outros princípios como boa-fé, confiança, etc., adotando-se o tratamento entificador do interesse público, abstratamente e dedutivamente aplicado aos casos concretos.

Materializar o princípio do interesse público encontra-se diretamente relacionado com a idéia de $P$ hýsis do pensamento grego, palavra-guia presente em tudo, constituindo-se, assim, o nome do ser. Segundo Martin Heidegger, significa o puro surgimento, em cujo domínio tudo o que aparece "é". ${ }^{73}$ Tratava-se daquela unidade originária que tudo congrega, mas que também está numa relação essencial com o adentrar no velamento, pois "surgindo, o surgimento favorece o fechamento, e de tal maneira que este vigora na própria essência do surgimento. Em se fechando, o fechar-se favorece o surgimento de tal maneira que este vigora a partir da própria essência do fechamento". ${ }^{74}$ Assim, quando se fala em interesse público, é importante para um pensamento originário não desconsiderar na própria idéia de interesse público a sua dimensão de ocultamento e que, tradicionalmente,

\footnotetext{
$\overline{73}$ Herakilt. HEIDEGGER, Martin. Heráclito. A Origem do Pensamento Ocidental. Rio de Janeiro: Relume Dumará, 1998, p. 114. Refere o autor a phýsis como puro surgimento, mas como uma espécie de invólucro capaz de tudo abranger, onde jogamos e empacotamos nossa representação moderna das coisas como entes.

${ }^{74}$ HEIDEGGER, Martin. Heráclito, p. 147.
}

A \& C R. de Dir. Administrativo e Constitucional, Belo Horizonte, ano 4, n. 18, p. 107-145, out./dez. 2004 
tem sido construída como a noção de interesse privado. A oposição público/ privado não é recente, relacionando-se com o conjunto de interesse que ora pertencem ao grupo social ou aos indivíduos singularmente, assumindo esta dicotomia função estruturante do poder político no Estado Moderno. ${ }^{75}$ Um dos grandes problemas decorrentes do modo de pensar objetificador foi compartimentalizar as noções de interesse público e privado, como se um não estivesse contido no outro. Para Martin Heidegger, "a representação compartimental não é, de modo algum, apenas a conseqüência de um modo superficial de pensar, mas o seu fundamento e a sua base. $\mathrm{O}$ pensamento compartimental funda-se no fato de que o ente se impõe por si mesmo, no sentido de tornar-se e manter-se o paradigma e a perspectiva de determinação do ser" ${ }^{76}$ É claro, não se desconhece as conjunturas políticas, históricas e sociais que engendraram esta separação, bem como os efeitos para a comunidade, como o processo de despatrimonialização e despersonalização do poder, na medida em que há necessidade de ser exercido o controle sobre a sua utilização por parte do soberano, não sendo mais apropriado patrimonialisticamente ou submetido a um conjunto de critérios pessoais. ${ }^{77} \mathrm{~A}$ dicotomização entre a esfera pública e privada, com efeito, funcionou como elemento de racionalização, o que foi determinante para a imperiosidade de seu elevado grau de abstração, como até mesmo mecanismo de justificação da imposição de restrições aos interesses individuais, em nome "do interesse público". Verifica-se, desta forma, na própria construção desta verdadeira "separação" a permanente tensão entre o que está restrito à atuação dos indivíduos e o espaço previamente delimitado da ação coletiva.

Obviamente não se está defendendo a necessidade de uma postura individualista, mas sim denunciando a presença de um equívoco na construção teórica do já referido princípio (da supremacia) do interesse público sobre o privado, pois não se compreende o que há de mais essencial e originário

\footnotetext{
75 Sobre o tema ver BOBBIO, Norberto. Estado, Governo e Sociedade. Para uma Teoria Geral da Política. 4. ed. Rio de Janeiro: Paz e Terra, 1992, p. 13, bem como o estudo monográfico de MARQUES NETO, Floriano Peixoto de Azevedo. Regulação Estatal e Interesses Públicos. No seu entendimento: "a separação entre as esferas públicas e privadas se manifestará, portanto, pela definição da primeira como o predomínio da vida econômica e da ação do indivíduo (despida da imposição de limites e controles), e da segunda como o campo de exercício deste poder, restrita à imposição de regras de convívio e de gestão da coletividade naquilo que, ao longo do tempo, foi-se fazendo necessário para a manutenção das condições básicas de preservação do sistema econômico e social" (Id., p. 43). Em outra passagem, aduz: "...a centralidade da separação entre estas duas esferas decorre, de um lado, da necessidade, ditada pela afirmação do modelo capitalista, de um espaço de atuação livre dos agentes econômicos e, de outro, da já aludida tensão pela restrição do exercício do poder político e conseqüente afirmação da esfera de autonomia dos indivíduos" (Id., p. 47)

76 HEIDEGGER, Martin. Heráclito, p. 147.

${ }^{77}$ Cf. MARQUES NETO, Floriano Peixoto de Azevedo. Regulação Estatal e Interesses Públicos, p. 45.
} 
que é a "junção", no sentido grego de que a phýsis determina a conjugação entre aquilo que encobre com o surgir, ou seja, estabelecendo a relação com o tema tratado, no público surge o privado e no privado surge o público e é exatamente nesta junção que exsurgem as condições de possibilidade de sua abertura e desvelamento com a ponderação de todos os interesses envolvidos. ${ }^{78} \mathrm{O}$ ponderar é a via necessária para perceber a divergência entre público e privado como entes que se dão no seu ser e que o divergir há de ser apreendido como um coordenar. ${ }^{79} \mathrm{O}$ modo de pensar objetificador possui grandes dificuldades para pensar público/privado não como entes simplesmente justapostos, mas que surgem na junção dos divergentes. No campo específico do sentido comum teórico do Direito Administrativo, este elemento fica acentuado em virtude desta construção fundante possuir em suas bases paradigmáticas a necessidade de instrumentalizar um conjunto de parâmetros normativos capaz de delimitar a atuação administrativa, de modo a não ter ingerências abusivas na esfera dos cidadãos, mais uma vez dicotomizando-se o modo de ser do poder político. ${ }^{80}$

Como referência do pensar entificador sobre o interesse público, é emblemática a seguinte decisão do Supremo Tribunal Federal: "Interpretação conforme a Constituição. A imissão na posse em caso de urgência, previsto no $\S 1^{\circ}$ e suas alíneas ou art. 15 do decreto-lei $\mathrm{n}^{\mathrm{o}} 3.365 / 41$ é provisória e dispensa prévia avaliação. Na hipótese, perde-se apenas a posse, e não

\footnotetext{
${ }^{78}$ No entanto, desde já deve ficar esclarecido que a impossibilidade fenomenológica de tratar a conjunção dos interesses a serem tutelados pela Administração Pública com a dicotomização "interesse público" e " interesse privado", não pode levar à admissibilidade ou permissibilidade de práticas capazes de velar tais interesses, como atos de improbidade administrativa, malversação de verbas públicas, favoritismos políticos, perseguições, etc. Aliás, esta espécie de individualismo foi determinante historicamente para que fosse estabelecida esta separação entre o público e o privado, justificando-se a idéia de que para salvaguardar o interesse de todos da comunidade seria imperioso negar os interesse privados (cf. MARQUES NETO, Floriano Peixoto de Azevedo. Regulação Estatal e Interesses Públicos, p. 82).

79 Cf. HEIDEGGER, Martin. Heráclito, p. 158.

${ }^{80}$ Cf. MARQUES NETO, Floriano Peixoto de Azevedo. Regulação Estatal e Interesses Públicos, p. 70. Menciona o autor ser o caráter autoritário e unilateral do Direito Administrativo conseqüência deste processo: "O que desejamos destacar é o fato de que o Direito Público e - por conseguinte - o Direito Administrativo herdam o caráter impositivo, autoritário, unilateral, decorrente do fato de ser o espaço público o primado da autoridade, do poder soberano, que como tal só faz sentido se sobreposto aos interesses dos indivíduos" (Id., p. 72).

${ }^{81}$ BRASIL. Supremo Tribunal Federal. Rec. Ext. n 170.931, Pleno, STF, Redator p/ o acórdão Min. Moreira Alves, j. 12.06.97, RDA, n. 215, jan./mar. 1999, p. 245. Neste julgado a discussão situa-se na interpretação das expressões "imissão provisória" na posse (artigo 15 do DL n 3.365/41) e "justa indenização" (artigo 5, inciso XXIV, CF). Discutiu-se, em última análise, a prevalência do princípio da supremacia do interesse público da Administração Pública em obter, de forme célere, a utilização de imóvel desapropriado, sem que previamente fosse realizada avaliação judicial provisória para determinar o valor a ser inicialmente depositado. Em contrapartida, estava em jogo o direito à propriedade privada do administrado que, com o deferimento da imissão provisória, seria impedido de utilizar o referido bem e, ao mesmo tempo, não obteria o valor necessário para a aquisição de imóvel equivalente. Vale referir que o Governo Federal, com objetivo de modificar algumas regras referentes à desapropriação e outras matérias, editou sucessivas medidas provisórias para alterar o Decreto-Lei $n^{\circ}$ 3.365/41, sendo que a MP n².183-54, de 28 de junho de 2001, deu a seguinte redação para o "caput" do artigo 15 e seus parágrafos, debatidos no acórdão mencionado: "Art.

A \& C R. de Dir. Administrativo e Constitucional, Belo Horizonte, ano 4, n. 18, p. 107-145, out./dez. 2004
} 
a propriedade do bem. Perda de posse em razão de imissão provisória é coberta mediante juros compensatórios, e não juros moratórios" ${ }^{81}$ Situado no pensar que vela o modo-de-ser do interesse público, adotou-se a posição de onticamente compreender o princípio em tela, deixando de lançar a interrogação pelo sentido na sua ponderação com o privado. Ao contrário, o público foi vislumbrado dedutivamente como o interesse universal e abstrato pertencente à Administração Pública, não sendo, portanto, exigível a realização de qualquer avaliação prévia para conceder a imissão provisória na posse. Olvidou-se que não há como dicotomizar o interesse público do interesse privado, sob pena de incidir na objetificação, até porque também é de interesse público criar as condições de possibilidade para o cidadão adquirir outra moradia, desvelando-se o ente propriedade no modo-de-ser do Estado Democrático de Direito, figurando a moradia, inclusive, como direito social previsto no artigo $6^{\circ}$ da Constituição Federal. Logo, compreender o interesse público a partir da ponderação, considerada hermeneuticamente, importa em não adotar a postura universalizante, como poderia indicar o princípio da "supremacia" do interesse público, mas interrogar sobre a re-união dos diversos âmbitos de sentido dos entes jurídicos.

Deve-se dizer, por vezes, encontram-se julgados nos quais o senso comum, de cariz metafísico-objetificante sobre o interesse público, é ultrapassado. Como no outro Caso de Remoção do Servidor julgado pela $3^{\text {a }}$ Câmara Cível do Tribunal de Justiça do Estado ${ }^{82}$ no qual foi julgado mandado de segurança impetrado por servidora, com a finalidade de anular portarias expedidas pela Administração Pública, removendo-a para exercer suas atividades em Unidade de Saúde distante $15 \mathrm{~km}$ de sua residência, sob a alegação de interesse público. Neste feito, deixou-se de adotar a postura abstrata e entificadora sobre o ente interesse público, lançando-se na ponderação das circunstâncias do caso concreto e a partir de um círculo hermenêutico principial, prevalecendo o entendimento de nulidade das Portarias, pois houve por parte do Poder Público Municipal a utilização do interesse público, de forma genérica, e sem referência à realidade

15-A. No caso de imissão prévia na posse, na desapropriação por necessidade ou utilidade pública e interesse social, inclusive para fins de reforma agrária, havendo divergência entre o preço ofertado em juízo e o valor do bem, fixado na sentença, expressos em termos reais, incidirão juros compensatórios de até seis por cento ao ano sobre o valor da diferença eventualmente apurada, a contar da imissão na posse, vedado o cálculo de juros compostos"

${ }^{82}$ RIO GRANDE DO SUL. Tribunal de Justiça. Reexame Necessário nº 70002452365, $3^{a}$ CC, TJRS, Rel. Des. Perciano de Castilhos Bertoluci, j. 23.08.01.

A \& C R. de Dir. Administrativo e Constitucional, Belo Horizonte, ano 4, n. 18, p. 107-145, out./dez. 2004 
fática do caso concreto. Em última análise, o público somente apareceria pela reflexão fenomenológica com o privado, o interesse da servidora em permanecer lotada na sua unidade de origem, mergulhando-se na tensão desta divergência.

A Administração Pública, deste modo, lida com uma unidade de interesses em constante relação - público-privado - , exigindo-se a tarefa ôntico-ontológica de ponderação dos interesses em jogo. Tal forma de compreender o ente interesse público impede a utilização do dogma de sua supremacia sobre o privado, pois no ser (sentido) deste ente não há uma relação de supremacia, mas de consonância e dissonância. A ponderação, também, apresenta-se primordial para lidar com as complexidades do Estado Democrático de Direito, no qual há abundância da pluralidade de interesses, sendo cada vez mais difícil para o operador do Direito identificar, sem cair na representação, o que é um interesse público, com exclusividade, e o que seria o interesse privado, apenas como tal, ressalvadas, por óbvio, as práticas já aludidas que importam em velar o modo-de-ser-da-democracia, como transparência, respeito aos direitos fundamentais, cuidado com a coisa pública, etc. De qualquer sorte, aquele modo-de-ser que impede o autêntico acontecer da Constituição, deve ser coibido não porque haja uma supremacia do público, mas em decorrência de apresentar-se como um agir divorciado do caminho fenomenológico até então percorrido e conquistado pelo Direito Administrativo, caminho este desvelado a partir do específico horizonte de uma tradição de sentido democrático.

Com efeito, busca-se apenas ressaltar que "diante da crescente fragmentação social, parece não ser mais válido falar de uma só unidade homogênea do público ou do coletivo, mas uma constelação de unidades orgânicas mais e mais multifacetadas e passíveis de agregações transitórias". ${ }^{83}$ Um modo de pensar a partir da filosofia hermenêutica, não pode trabalhar com a idéia de homogeneidade na esfera dos interesses públicos ou no âmbito dos interesses privados, e, por via reflexa, da absoluta relação de oposição entre tais campos de ação. Sobre este tema, interessante colacionar a posição de Humberto Bergmann Ávila, para quem na própria

\footnotetext{
${ }^{83}$ Cf. MARQUES NETO, Floriano Peixoto de Azevedo. Regulação Estatal e Interesses Públicos, p. 146.

${ }^{84}$ ÁVILA, Humberto Bergmann. Repensando a Supremacia do Interesse Público sobre o Particular, p. 122-

123. Este autor entende ser necessário superar o princípio da supremacia do interesse público sobre o privado, considerando o distanciamento desta pauta normativa da vetusta idéia de bem comum, e que, para ele, não se constitui em verdadeiro princípio. Menciona a lição de ISENSEE, Josef. Gemeinwohl und Staatsaufgaben in Verfassungsstaat. In: HStr III, § 57 Rn 19, "na prática política é bastante discutido o que proporciona o interesse público numa concreta situação, se ele obtém a primazia frente a interesses
} 
definição de interesse público estariam contidos elementos privados, descabendo falar-se em automática supremacia dos interesses públicos, exigindo-se a ponderação não somente dos interesses reciprocamente implicados, mas, também, dos interesses públicos em si. ${ }^{84}$ Pode-se sustentar, a ponderação representa para o Direito Administrativo uma valiosa recepção hermenêutica, por óbvio, não se apresentando como um Grundmethode,$^{85}$ mas existencial importante para lidar com a complexidade jurídica do regime de prerrogativas e limites da Administração Pública, considerando especialmente seu caráter principial.

\section{Considerações finais}

Do que acima restou explicitado, cada vez mais são importantes as pesquisas direcionadas para evidenciar as condições de possibilidades hermenêuticas no âmbito do Direito Administrativo. Partindo-se do interesse público, como exemplo privilegiado para tratar deste tema, é crível sustentar: a) o interesse público, sob pena de uma dicotomização formalista, não pode ser compreendido como aquele pertencente tão-somente ao espaço estatal e tudo aquilo que gire na órbita dos espaços não-estatais serem tratados com um caráter de submissão dogmática; b) interesse público não é um conceito metafísico, pronto e acabado para ser acoplado subsuntivamente, mas ente jurídico a ser desvelado a partir de um conjunto de indícios formaisconstitucionais, desvelado pelas possibilidades de cada situação concreta; c) a applicatio de Hans-Georg Gadamer é importante para que o operador do direito vislumbre que o interesse público apenas acontece na esfera do agir ponderativo, assumindo o cidadão papel relevante na participação de sentido; d) por certo não se modifica uma tradição racional-formalista abruptamente, sendo preciso desenvolver uma experiência ontológica de interesse público, na qual o modo-de-ser dos princípios fundamentais do artigo $3^{\circ}$ da Constituição Federal podem ser relevantes neste caminho a ser construído dialogiamente, mas sem cair no império da representação; e) particulares colidentes ou como deve ser obtido um ajuste. Mas não se trata de medidas inconciliąveis ou antinômicas. Então o bem comum inclui o bem de suas partes (...) Interesses privados podem transformarse em públicos. Bonum commune e bonum particulare exigem-se reciprocamente. Essa principal coordenação exclui uma irreconciliável contraposição. A tensão entre ambos é, no entanto, evidente". Portanto, defende a tese de que o bem comum seria o elemento aglutinador do público e do privado, apresentando-se necessária a atividade de ponderação, orientada para o caso particular e para a constituição. Salienta, inclusive, que o surgimento de novas relações jurídicas, como as de cooperação em áreas como meio ambiente, saúde pública, etc. estariam a exigir nova postura para explicar o que se denomina de relação multipolar, apresentando-se insuficiente a análise do Direito Administrativo calcada na contraposição entre Estado e cidadão e entre interesse público e o interesses privado (Id., p. 123).

${ }^{85}$ Expressão esta criada por STRECK, Lênio Luiz. Hermenêutica Jurídica e $(m)$ Crise. Porto Alegre: Liv. do Advogado, 2003

${ }^{86}$ HEIDEGGER, Martin. Hölderlin y la Esencia de la Poesia. Anthropos Editorial, 2000, p. 16-39. 
tal acontecer também exigirá uma nova linguagem, na qual a palavra do constitucionalismo moderno assuma a dianteira, pois, como mencionava Martin Heidegger, ${ }^{86}$ a palavra seria um bem do homem capaz de possibilitar o genuíno dizer, sendo que o constitucionalismo, como verdadeiro acontecer histórico e determinando o modo-de-ser da Constituição possibilita o mais genuíno dizer do princípios da Administração Pública; f) a palavra constitucional, com efeito, não é mero instrumento à disposição dos operadores do direito, mas ela proporciona a garantia de manter firme o Estado Democrático de Direito frente aos entes administrativos, até porque "unicamente onde há palavra há mundo", como mencionava o Filósofo da Floresta Negra e g) se hoje, como mencionado ao longo deste estudo, não há o acontecer do interesse público-democrático, tal ocorre porque, muitas vezes, falta a palavra constitucionalizante, impedindo o próprio acontecer do horizonte histórico do constitucionalismo moderno.

\section{Referências}

ALMEIDA, Luís Silva de. Hermenêutica e Dialética: dos Estudos Platônicos ao Encontro com Hegel. Porto Alegre: EDIPUCRS, 2002.

ÁVILA, Humberto Bergmann. Repensando a Supremacia do Interesse Público sobre o Particular. In: O Direito Público em Tempos de Crise. Estudos em homenagem a Ruy Ruben Ruschel. Porto Alegre: Liv. do Advogado, 1999, p. 99-127.

BARROSO, Luís Roberto. Fundamentos Teóricos e Filosóficos do Novo Direito Constitucional Brasileiro (Pós-Modernidade, Teoria Crítica e Pós-Positivismo). Cadernos de Soluções Constitucionais, São Paulo, n. 1, p. 150-84, 2003.

BOBBIO, Norberto. Estado, Governo e Sociedade. Para uma Teoria Geral da Política. 4. ed. Rio de Janeiro: Paz e Terra, 1992.

BONAVIDES, Paulo. Curso de Direito Constitucional. 6. ed. São Paulo: Malheiros, 1996.

BORGES, José Souto Maior. Pró-Dogmática: por uma Hierarquização dos Princípios Constitucionais. RTDP, São Paulo, n. 1, p. 143-44, 1993.

CAPELLA, Juan Ramón. Fruta Prohibida. Una Aproximación Histórico-teorética al Estudio del Derecho y del Estado. Madrid: Trotta, 1997.

CORETH, Emerich. Questões Fundamentais de Hermenêutica. São Paulo: EDUSP, 1973.

DUPUIS, George. Droit Administratif. 5. ed. Paris: Armand Colin, 1996.

DUTT, Casten. En conversación com Hans-Georg Gadamer. Hermenéutica/Estética/Filosofia Practica. Madrid: Editorial Tecnos, 1998.

ENTERRÍA, Eduardo Garcia de. Revolucion Francesa y Administración Contemporanea. Madrid: Editorial Civitas, 1998.

ESCOLA, Hector. El Interés Público como Fundamento del Derecho Administrativo. Buenos Aires:

A \& C R. de Dir. Administrativo e Constitucional, Belo Horizonte, ano 4, n. 18, p. 107-145, out./dez. 2004 
Depalma, 1989.

FERNANDEZ-LARGO, Antonio Osuna. La Hermenéutica Jurídica de Hans-Georg Gadamer. Valladolid: Secretraria de Publicaciones, Universidad, D. L., 1992.

FERREIRA PINTO DIAS GARCIA, Maria da Glória. Da Justiça Administrativa em Portugal: sua Origem e Evolução. Lisboa: Universidade Católica Editora, 1994.

FLICKINGER, Hans-Georg. Da Experiência da Arte à Hermenêutica Filosófica. In: Hermenêutica Filosófica: nas Trilhas de Hans-Georg Gadamer. Porto Alegre: EDIPUCRS, 2000.

FREITAS, Juarez. Do Princípio da Probidade Administrativa e de sua Máxima Efetivação. $R D A$, Rio de Janeiro, v. 204, p. 65-84, p. 68

FREITAS, Juarez. O Controle dos Atos Administrativos e os Principios Fundamentais. 2. ed. São Paulo: Malheiros, 1999.

GADAMER, Hans-Georg. Hermenéutica y Autoridad: un Balance. In: Acotaciones Hermenéutica. Madrid: Trotta, 2002, p. 59-66.

GADAMER, Hans-Georg. Verdad y Método I. Fundamentos de una Hermenéutica Filosófica. 5. ed. Salamanca: Sigueme, 1993.

GARCÍA, Manuel Calvo. Los Fundamentos Del Método Jurídico: una Revisión Crítica. Madrid: Tecnos, 1994

GRAU, Eros Roberto. Ensaio e Discruso sobre a Interpretação/Aplicação do Direito. São Paulo: Malheiros, 2002.

GRONDIN, Jean. Hans-Georg Gadamer. Una biografia. Barcelona: Herder, 2000.

GRONDIN, Jean. Introducción a Gadamer. Madrid: Herder, 2003.

HARGER, Marcelo. Reflexões Iniciais sobre o Princípio da Eficiência. RDA, Rio de Janeiro, n. 217 , p. $151-56$

HEIDEGGER, Martin. Heráclito. A origem do pensamento ocidental. Rio de Janeiro: Relume Dumará, 1998.

HEIDEGGER, Martin. La Época de La Imagen Del Mundo. In: Caminos de Bosque. Madrid: Alianza Editorial, 1998.

HEIDEGGER, Martin. La Pergunta por la Técnica. In: Conferencias y Articulos. Barcelona: Ediciones del Serbal, 1994, p. 9-37.

HEIDEGGER, Martin. Hölderlin y la Esencia de la Poesía. Anthropos Editorial, 2000.

LAMEGO, José. Hermenêutica e Jurisprudência. Análise de uma Recepção. Lisboa: Fragmentos, 1990.

MARQUES NETO, Floriano Peixoto de Azevedo. Regulação Estatal e Interesses Públicos. São Paulo: Malheiros, 2002.

MEIRELLES, Hely Lopes. Direito Administrativo Brasileiro. 24. ed. São Paulo: Malheiros, 1999.

MELLO, Celso Antônio Bandeira de. O Princípio do Enriquecimento sem Causa em Direito Administrativo. RDA, Rio de Janeiro, v. 210, p. 25-35, out./dez. 1997.

MELLO, Celso Antônio Bandeira de. Poder Regulamentar ante o Princípio da Legalidade. Revista Trimestral de Direito Público, São Paulo, n. 4, p. 71-83, 1993.

A \& C R. de Dir. Administrativo e Constitucional, Belo Horizonte, ano 4, n. 18, p. 107-145, out./dez. 2004 
MICHELAZZO, José. Do Um como Princípio ao Dois como Unidade: Heidegger e a Reconstrução Ontológica do Real. São Paulo: FAPESP, Annablume, 1996.

NOBRE JR., Edilson Pereira. Princípios Retores da Desapropriação. RDA, Rio de Janeiro, n. 209, p. 121-41, jul./set. 1997.

OHLWEILER, Leonel. A Ponderação no Regime Administrativo Brasileiro: Contributo da Fenomenologia Hermenêutica. Tese (Doutorado) - UNISINOS, São Leopoldo, 2003.

OLIVEIRA, Manfredo Araújo de. Reviravolta Lingüístico-Pragmática na Filosofia Contemporânea . São Paulo: Loyola, 1996.

PEIXINHO, Manoel Messias. Princípios Constitucionais da Administração Pública. In: Os Princípios da Constituição de 1988. Rio de Janeiro: Lumen Juris, 2001, p. 447-474.

PUCEIRO, Enrique Zuleta. Paradigma Dogmático y Ciencia Del Derecho. Madrid: Editoriales de Derecho Reunidas, 1981.

ROCHA, Carmen Lúcia Antunes. Princípio Constitucionais da Administração Pública. Belo Horizonte: Del Rey, 1994.

SANCHÍS, Luis Prieto. Sobre Principios y Normas: Problemas del Razonamiento Jurídico. Madrid: Centro de Estudios Constitucionales, 1992.

STEIN, Ernildo. Aproximações Hermenêuticas. Porto Alegre: EDIPUCRS, 1996.

STRECK, Lenio Luiz. Hermenêutica Jurídica e $(m)$ Crise. 4. ed. Porto Alegre: Liv. do Advogado, 2003.

STRECK, Lenio Luiz; MORAIS, José Luiz Bolzan de. Ciência Política e Teoria Geral do Estado. Porto Alegre: Liv. do Advogado, 2000.

TÁCITO, Caio. O Princípio de Legalidade: Ponto e Contraponto. RDA, Rio de Janeiro, v. 